\title{
SPECIFIC VOLUME OF LIQUID AMMONIA
}

\author{
By C. S. Cragoe and D. R. Harper 3d
}

\section{ABSTRACT}

The specific volume-that is, the numerical reciprocal of density-of pure liquid ammonia under the pressure corresponding to saturation conditions was determined throughout the temperature interval -78 to $+100^{\circ} \mathrm{C}$, with an accuracy of about 1 part in 10000 . A comprehensive review of previous work is included. Tables of specific volume and density in both metric and Fnglish units are appended.

\section{CONTENTS}

I. Introduction $\ldots \ldots \ldots \ldots \ldots \ldots \ldots \ldots \ldots \ldots \ldots \ldots \ldots \ldots \ldots \ldots \ldots \ldots \ldots, 287$

II. Previous measurements.................................. 288

III. Description of method and design of picnometers................ 292

IV. General description of apparatus ............................. 295

x. Picnometers.................................. 295

2. Balance and weighing chamber...................... 297

3. Thermoregulated bath............................. 297

4. Thermometers.................................... 298

V. Calibration of picnometers . . . . . . . . . . . .

VI. Purification of samples and description of picnometer fillings......... $30 \mathrm{I}$

VII. Results of measurements ................................ \$04

VIII. Form of empirical equation to represent specific volume of liquid ammonia as a function of temperature $\ldots \ldots \ldots \ldots \ldots \ldots \ldots \ldots \ldots \ldots, 307$

IX. Discussion of results . . . . . . . . . . . . . . .

$\mathrm{X}$. Sunmary $\ldots \ldots \ldots \ldots \ldots \ldots \ldots \ldots \ldots \ldots \ldots \ldots \ldots \ldots \ldots \ldots, 3_{11}$

Appendix:-Tables of specific volume and density of liquid ammonia under saturation pressure in metric and English units.................. $3^{13}$

\section{INTRODUCTION}

The extensive use of ammonia in the refrigerating industries lends commercial importance as well as scientific interest to the accurate measurement of its physical properties. Among the properties which are necessary to the preparation of engineering tables for this industry is the specific volume, namely the volume occupied by unit mass, or the numerical reciprocal of density.

Direct measurements of this property of the vapor under saturation conditions were undertaken at this Bureau some time ago. The method employed in these measurements (which will be published later) required an accurate knowledge of the specific volume 
of the saturated liquid; that is, under the pressure corresponding to saturation conditions. It was to meet this requirement that the measurements here presented were made. They serve also as a convenient means of the several samples of ammonia purified by somewhat different methods and used in the determinations of the various thermodynamic properties of ammonia. ${ }^{1}$

\section{PREVIOUS MEASUREMENTS}

The earliest measurements were made with apparatus that did not lend itself to precision work, and also under very unfavorable conditions, so that no great significance is to be attached to the results. They have historic interest, in common with pioneer measurements of any kind, and are accordingly summarized in Table I, but do not merit individual detailed discussion. For comparison, the authors' results are included in the last column.

TABLE 1.-Early Measurements of the Specific Volume of Liquid Ammonia, in Cubic Centimeters per Gram

\begin{tabular}{|c|c|c|c|c|c|c|c|}
\hline $\begin{array}{c}\text { Temperature in degrees } \\
\text { centigrade }\end{array}$ & $\begin{array}{c}\text { Faradeya } a \\
\text { (1823) }\end{array}$ & $\begin{array}{c}\text { Andreef } b \\
\text { (1859) }\end{array}$ & $\begin{array}{l}\text { Jolly ce } \\
\text { (1861) }\end{array}$ & Lunged & $\begin{array}{l}\text { Lange } \\
\text { and } \\
\text { Hertz } \\
\text { (1897) }\end{array}$ & $\begin{array}{l}\text { Urban } f \\
\text { (1897) }\end{array}$ & $\begin{array}{l}\text { Burean } \\
\text { of Stand- } \\
\text { ards } \\
(1920)\end{array}$ \\
\hline 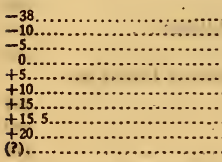 & $\begin{array}{r}1.32 \\
1.368\end{array}$ & $\begin{array}{r}1.540 \\
1.555 \\
1.571 \\
1.588 \\
1.605 \\
1.623 \\
1.642 \\
\cdots \cdots \cdots\end{array}$ & $\begin{array}{r} \\
\cdots \\
\cdots \\
\cdots\end{array}$ & 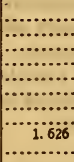 & 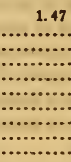 & 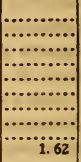 & $\begin{array}{l}1.4545 \\
1.5338 \\
1.5496 \\
1.5660 \\
1.5831 \\
1.6008 \\
1.6193 \\
1.6212 \\
1.6386\end{array}$ \\
\hline
\end{tabular}

a Phil. Trans. Roy. Soc., London, 113, p. 197; 1823. Pbil. Trans. Roy. Soc., London, 185, p. 169; 1845. Collected works, edition of 1859 , pp. 95 and 114.

b Ann. d. Chemie und Pharmacie (Liebig's), 110, p. r; 1859.

c Ann. d. Chemie und Pharmacie (Liebig's), 117, p. 181; 1861. Phil. Mag. (4), 21, D. 364: 1861.

d Taschenbuch der soda industrie (inaccessible, and figures taken from Lange, see footnote 2).

e.Zeitschrift iür angewandte chemie, p. 224; 8897.

1 Chemikerzeitung, 21, p. 720; 1897 .

The first measurement worthy of detailed consideration is that made by Lange ${ }^{2}$ in 1898 . The method was to fill a bomb almost full of ammonia at a temperature somewhat below that desired for a determination, connect the bomb to a manometer, and immerse it in a bath the temperature of which could be raised at a suitable rate. Complete fullness of the system was indicated by the

\footnotetext{
${ }^{1}$ Latent heat of vaporization, B. S. Bull, 14, p. 439; 1917 (Scientific Paper No. 315). Specific heat, B. S. Bull. 14, p. 397; 1917 (Scientific Paper No. 313). Vapor pressure, B. S. Bull., 16, p. 1; 1920 (Scientific Pa. per No. 369 ).

'Chemische Industrie, 21, p. 191; 1898. Zs. f. d. gesamte kälte-industrie, 5, p. 39; 1898 .
} 
manometer changing its rate of rise from that corresponding to increase of vapor pressure to that corresponding to the expansion of the liquid. The temperature was then noted, the outlet valve of the bomb closed so as to entrap a definite volume of ammonia, and the temperature at once lowered to prevent bursting. Necessary weighings and volumetric calibrations supplied the data for the density. An effort was made to exclude errors due to air. For temperatures below that of the weighing room, a modification of the above method was made by introducing a series of overflow or spill bombs. The principles were not altered, only a considerable increase made in the number of necessary weighings. The series of determinations, made with a bomb of about I.I7 liters capacity, is given in Table 2 .

TABLE 2.--Measurements by Lange

\begin{tabular}{|c|c|c|c|}
\hline Temperature in degrees centigrade & $\begin{array}{l}\text { Specific } \\
\text { volume }\end{array}$ & Temperature in degrees centigrade & $\begin{array}{l}\text { Specific } \\
\text { volume }\end{array}$ \\
\hline 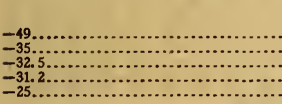 & $\begin{array}{c}\mathrm{cm} 3 / \mathrm{g} \\
1.4403 \\
1.4747 \\
1.4832 \\
1.4881 \\
1.5038\end{array}$ & $\begin{array}{l}+36.7 \\
+40.8 \ldots \ldots \\
+44.7 \ldots \ldots \\
+48.6 \ldots \ldots \\
+52.5 \ldots \ldots\end{array}$ & $\begin{array}{c}\mathrm{cm} / \mathrm{g} \\
1.7221 \\
1.7425 \\
1.7630 \\
1.7838 \\
1.8051\end{array}$ \\
\hline 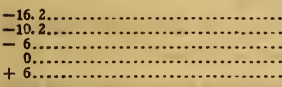 & $\begin{array}{l}1.5305 \\
1.5413 \\
1.5605 \\
1.5770 \\
1.5985\end{array}$ & 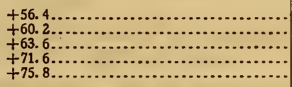 & $\begin{array}{l}1.8275 \\
1.8505 \\
1.8727 \\
1.9301 \\
1.9623\end{array}$ \\
\hline 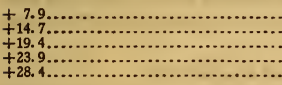 & $\begin{array}{l}1.6090 \\
1.6284 \\
1.6469 \\
1.6647 \\
1.6838\end{array}$ & $\begin{array}{l}+78.8 \\
+81.8 \ldots \ldots \ldots \ldots \\
+84.7 \ldots \ldots \\
+90.2 \ldots \ldots \\
+97.8 \ldots \ldots\end{array}$ & $\begin{array}{l}1.9869 \\
2.0137 \\
2.0412 \\
2.0960 \\
2.1853\end{array}$ \\
\hline+32.6 & 1. 7021 & & \\
\hline
\end{tabular}

Lange computed a smoothed table of results from the above data. These are given in Table 5 , and the percentage deviations from the results of the present work are plotted as a smooth curve in Fig. 1 . The report of the work is comprehensive and offers fair information for analysis, but it has not seemed possible to locate a probable error of I per cent throughout the range.

The measurements by Dieterici and Drewes ${ }^{3}$ were made in calibrated glass containers. The method employed is discussed briefly in the following section. An accuracy of $0 . \mathrm{I}$ per cent is claimed for the results, but the report is entirely lacking in those details which would permit an independent estimate of final accuracy, or even the precision attainable in the apparatus used. The individual observations show an average deviation from the mean

Zs. f. d. gesamte kälte-industrie, 11, p. 21; 1904 . 
curve of about I part in rooo. The observations extended from 0 to $+105^{\circ} \mathrm{C}$ and are given in Table 3. Dieterici gives a table of interpolated values between $\mathrm{O}$ and $100^{\circ} \mathrm{C}$ which are shown in Table 5 .

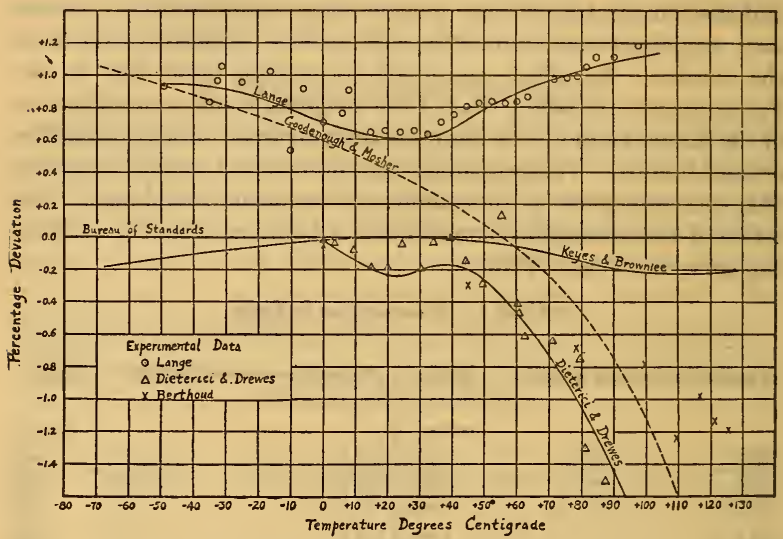

FIG. I.-Comparison of laboratory measurements, since 1898 , of the specific volume of anhydrous liquid ammonia under saturation pressure

(The dotted curve is from the tabuatilon by Goodenough and Mosher and does not represent an inde. pendent laboratory measurement.) The scale adopted was selected so that a deviation of $\mathrm{I}$ part in 10000 can be distinguished

TABLE 3.-Measurements by Dieterici and Drewes

\begin{tabular}{|c|c|c|c|}
\hline \multicolumn{2}{|l|}{ By Dieterci } & \multicolumn{2}{|l|}{ By Drewes } \\
\hline Temperature in degrees centigrade & $\begin{array}{l}\text { Specific } \\
\text { volume }\end{array}$ & Temperature in degrees centigrade & $\begin{array}{l}\text { Specific } \\
\text { volume }\end{array}$ \\
\hline 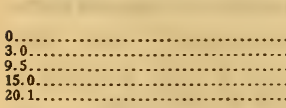 & $\begin{array}{c}\mathrm{cm}^{3} / \mathrm{g} \\
1.5656 \\
1.5769 \\
1.5977 \\
1.6161 \\
1.6358\end{array}$ & \begin{tabular}{|l} 
\\
55.4 \\
60.4 \\
60.9 \\
$62.8 \ldots \ldots$ \\
$71.1 \ldots \ldots \ldots$
\end{tabular} & $\begin{array}{c}\mathrm{cm} / / 8 \\
1.8090 \\
1.8289 \\
1.8309 \\
1.8403 \\
1.8957\end{array}$ \\
\hline 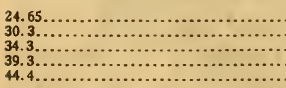 & $\begin{array}{l}1.6565 \\
1.6778 \\
1.6983 \\
1.7221 \\
1.7448\end{array}$ & 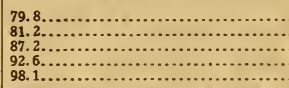 & $\begin{array}{l}1.9619 \\
1.9618 \\
2.0119 \\
2.0624 \\
2.1211\end{array}$ \\
\hline $49.6 \ldots$ & 1.7695 & 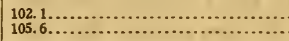 & $\begin{array}{l}2.1878 \\
2.2425\end{array}$ \\
\hline
\end{tabular}

Fitzgerald $^{4}$ in his work with ammonia solutions made several determinations of the specific volume of liquid ammonia at $-33.5^{\circ}$.

'J. Phys. Chem., 16, p. 654; 1912. 
He obtained as the mean of seven determinations $\mathrm{I} .4652 \mathrm{~cm} 3 / \mathrm{g}$, which agrees with the authors' measurements to about I part in 1000 .

In the research laboratory of the Massachusetts Institute of Technology, Keyes and Brownlee ${ }^{5}$ made a series of absolute measurements of specific volume at the normal boiling point, $0^{\circ}$, and $+35^{\circ} \mathrm{C}$, in a special picnometer, and a series of relative measurements at higher temperatures in a calibrated steel piston chamber. The specific volume at $+35^{\circ} \mathrm{C}$ was chosen as the reference point, and the increase in volume at higher temperatures was measured at pressures slightly greater than the saturation pressure. The individual determinations, made at about -33.5 , $\mathrm{O}, 35,68, \mathrm{I10}, \mathrm{I20}$, and $125^{\circ} \mathrm{C}$, are not recorded. Values are tabulated at $20^{\circ}$ intervals from -50 to $+120^{\circ} \mathrm{C}$, which are shown in Table 5 . The agreement with the results of the present work is remarkably good, as shown in Fig. $\mathbf{I}$.

Berthoud ${ }^{6}$ recently published his results on the specific volume of the saturated liquid and vapor of ammonia at high temperatures obtained in an attempt to determine the critical volume. Two calibrated glass tubes of different volumes were immersed in the vapors of various liquids boiling under a constant pressure, and the volumes of the liquid and vapor were observed in each tube. The temperatures in each experiment were obtained from the vapor-pressure curve of the particular liquid employed. No details are given which would permit an estimate of the precision attained. The results obtained are reproduced in Table 4. Berthoud plotted the observed liquid and vapor densities against temperature and estimated the critical density from the "slightly curved" rectilinear diameter. He gives no reason for the apparently arbitrary choice of the critical temperature.

TABLE 4.-Measurements by Berthoud

\begin{tabular}{|c|c|c|c|}
\hline Temperature in degrees centigrade & $\begin{array}{l}\text { Specific } \\
\text { volume }\end{array}$ & Temperature in degrees centigrade & $\begin{array}{l}\text { Specific } \\
\text { volume }\end{array}$ \\
\hline 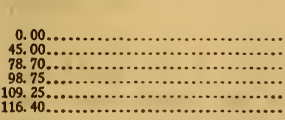 & $\begin{array}{l}\mathrm{cm} 8 / \mathrm{g} \\
1.5652 \\
1.7556 \\
1.9531 \\
2.1552 \\
2.3047 \\
2.4655\end{array}$ & 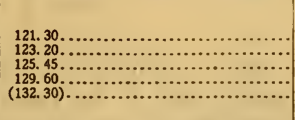 & $\begin{array}{l}\mathrm{cm}^{3} / \mathrm{g} \\
2.6103 \\
2.6667 \\
2.7902 \\
3.0807 \\
(4.2337)\end{array}$ \\
\hline
\end{tabular}

3 Thermodynamic properties of ammonia, John Wiley \& Sons; rgr6. J. Am. Soc. Refrigeration Engineers, 1, p. 34; 1914 .

- Helvitica chemica actB, 1, p. 84; 1918. 
TABLE 5.-Specific Volume of Ammonia under Saturation Pressure

[Smoothed values based on experimental measurements]

\begin{tabular}{|c|c|c|c|c|c|}
\hline \multirow[b]{2}{*}{ Temperature in degrees centigrade } & \multicolumn{5}{|c|}{ Specific volume } \\
\hline & $\begin{array}{c}\text { Lange } a \\
(1898)\end{array}$ & $\begin{array}{c}\text { Dieterici b } \\
\text { (1904) }\end{array}$ & $\begin{array}{l}\text { Good- } \\
\text { enough and } \\
\text { Mosher } c \\
\text { (1913) }\end{array}$ & $\begin{array}{c}\text { Keys and } \\
\text { Brownlee d } \\
(1916)\end{array}$ & $\begin{array}{c}\text { Bureau of } \\
\text { Standarda } \\
(1920)\end{array}$ \\
\hline 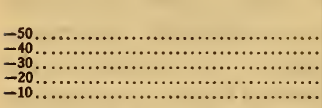 & $\begin{array}{c}\mathrm{cm}^{3} / \mathrm{g} \\
1.4380 \\
1.4631 \\
1.4892 \\
1.5167 \\
1.5458\end{array}$ & 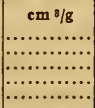 & $\begin{array}{c}\mathrm{cm}^{3} / \mathrm{g} \\
1.4377 \\
1.4621 \\
1.4876 \\
1.5151 \\
1.5439\end{array}$ & \begin{tabular}{|r|}
$\mathrm{cm} 8 / \mathrm{g}$ \\
1.4227 \\
$\cdots \cdots$ \\
1.4745 \\
$\cdots \cdots$ \\
1.5332
\end{tabular} & $\begin{array}{c}\mathrm{cm} / / 8 \\
1.4245 \\
1.4493 \\
1.4757 \\
1.5037 \\
1.5338\end{array}$ \\
\hline 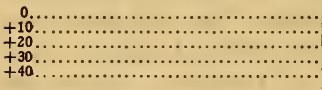 & $\begin{array}{l}1.5770 \\
1.6111 \\
1.6483 \\
1.6898 \\
1.7373\end{array}$ & $\begin{array}{l}1.5656 \\
1.5985 \\
1.6342 \\
1.6765 \\
1.7227\end{array}$ & $\begin{array}{l}1.5751 \\
1.6008 \\
1.6456 \\
1.6856 \\
1.7293\end{array}$ & $\begin{array}{r}1.5657 \\
1.6387 \\
1.7256\end{array}$ & $\begin{array}{l}1.5660 \\
1.6008 \\
1.6386 \\
1.6800 \\
1.7257\end{array}$ \\
\hline 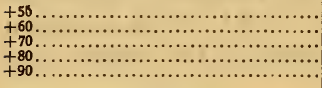 & $\begin{array}{l}1.7908 \\
1.8505 \\
1.9183 \\
1.9984 \\
2.0947\end{array}$ & $\begin{array}{l}1.7719 \\
1.8250 \\
1.8875 \\
1.9595 \\
2.0390\end{array}$ & $\begin{array}{l}1.7786 \\
1.8329 \\
1.8970 \\
1.9700 \\
2.0550\end{array}$ & 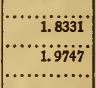 & $\begin{array}{l}1.7766 \\
1.8341 \\
1.9000 \\
1.9774 \\
2.0708\end{array}$ \\
\hline $\begin{array}{l}+100 \\
+120 \ldots \ldots \ldots \ldots \ldots \ldots \ldots \ldots \ldots \ldots \ldots \ldots \ldots \ldots \ldots \ldots \ldots \ldots \ldots \ldots \ldots \ldots\end{array}$ & 2.2114 & 2.1525 & $\begin{array}{l}2.1660 \\
2.4950\end{array}$ & $\begin{array}{l}2.1836 \\
2.5891\end{array}$ & $\begin{array}{l}2.1885 \\
2.5948\end{array}$ \\
\hline
\end{tabular}

a Chemische Industrie, 21, p. 191 ; 1898.

b Zs. f.d. gesamte kälte-industrie, 11, p. 21 ; 1904 .

$c$ These values are taken from Goodenough and Mosher's tables, Properties of saturated and superhested ammonia, University of Illinois Experiment Station Bulletin, 66; 1913 .

d Thermodynamic Properties of Ammonia, John Wiley \& Sons, 1916; J. Am. Soc. Refrigeration Engineers, 1, p. 34; ז914.

\section{DESCRIPTION OF METHOD AND DESIGN OF PIC- NOMETERS}

The method employed in the measurement of the specific volume of the liquid under saturation pressure was similar to that used by Dieterici. ${ }^{7}$ It consists essentially in observing, at various temperatures, the volumes of the liquid and vapor phases in equilibrium in a closed vessel.

Assuming that the two phases, liquid and vapor, are present and in equilibrium - that is, saturated-and that the walls of the vessel in the vapor space are dry, then at any given temperature the total mass of ammonia, $M$, in any closed vessel is given by the equation:

$$
M=\frac{v}{u}+\frac{V-v}{u^{\prime}},
$$

where $u$ and $u^{\prime}$ represent the specific volume of the liquid and vapor, respectively, $V$ the total volume of the vessel, and $v$ the volume of the liquid. In any experiment under saturation conditions the walls of the vapor space are very likely to be wet with a

7. f. d. gessmte kälte-industrie, 11, p. ax: 1904. 
thin film of liquid unless special precautions are taken to avoid this. However, if the volume of the vapor space is small, the mass of this film of liquid will be small in comparison with the total mass.

The method employed by Dieterici was to fill two vessels of different total volumes with equal masses of ammonia. Both vessels were immersed simultaneously in a thermoregulated bath, and observations were taken of the volume of liquid in each vessel. He then computed the ratio of the specific volumes at the various observed temperatures by the expression:

$$
R=\frac{u^{\prime}}{u}=\frac{\left(V_{2}-v_{2}\right)-\left(V_{1}-v_{1}\right)}{v_{1}-v_{2}}
$$

where the subscripts refer to vessels $I$ and 2 . With these values of $R$ the specific volume of the liquid was obtained from the measurements with the smaller vessel by means of the relation

$$
u=\frac{v}{M}+\frac{V-v}{M R}
$$

and finally $u^{\prime}$ from $R u=u^{\prime}$.

In the present investigation the procedure was simplified somewhat by designing vessels, here called picnometers, of widely different total volumes and filled with unequal masses of ammonia. From equation ( $\mathrm{I}$ ) the specific volume of the liquid and vapor may be expressed, respectively, as:

$$
\begin{gathered}
u=\frac{v}{M-\frac{V-v}{u^{\prime}}} \\
u^{\prime}=\frac{V-v}{M-\frac{v}{u}}
\end{gathered}
$$

in which $M, V$, and $v$ are the measurable quantities. It will be noted that both specific volumes $u$ and $u^{\prime}$ occur in each equation, but by suitable design of picnometers the terms $\frac{V-v}{u^{\prime}}$ or $\frac{v}{u}$ may be made small in comparison with $M$ such that they enter only as small correction terms. This may be accomplished with comparative ease in the determination of the specific volume of the liquid by designing picnometers of sufficient volume so that $M$, $56833^{\circ}-21-2$ 
$V$, and $v$ are easily measurable to the precision desired (about I part in 10000 in the present case) and so that the mass of the vapor, $\frac{V-v}{u^{\prime}}$, is not over o.I per cent of the total mass. Then by the use of approximate values of $u^{\prime}$ (within Io per cent), $u$ can be determined with the desired precision.

For determinations of the specific volume of the vapor, it is difficult and inconvenient to make the mass of the liquid, $\frac{v}{u}$, small in comparison with the total mass, especially at low temperatures, and it appeared desirable to determine first the specific volumes of the liquid with fair precision in order to make this correction with a satisfactory degree of certainty.

In a series of measurements of the specific volume of the liquid, the volume of the liquid in the picnometer was observed by reading at various temperatures the position of the meniscus upon a previously calibrated scale. The temperature of the thermoregulated bath was maintained constant to 0.01 or $0.02^{\circ} \mathrm{C}$ for an interval of about one-half hour and readings of the ammonia meniscus taken at 5 -minute intervals. The effect of drainage or evaporation of the liquid was found to be smáll, equilibrium being reached usually within ro minutes. The total volume of the picnometer was obtained from its calibration at the highest scale division visible and adding to this the estimated volume of the tip formed in sealing off. Both of these volumes were, of course, corrected for temperature and pressure changes. The total mass of ammonia in the picnometer was a constant during any series of measurements and was usually determined afterwards by weighing the picnometer filled with ammonia, then breaking the tip, and reweighing filled with dry air.

Considerable care was exercised in the determination of the mass. A short deep scratch was made at the tip of the picnometer with a diamond or special glass-cutting tool. The picnometer was then cleaned with chromic acid, water, and acetone, successively. After being permitted to hang in the weighing chamber for nearly an hour, in order to come to temperature equilibrium, it was weighed independently by two observers. In all of the weighings a counterpoise of equal external volume was employed and weighings, were made by substitution. The picnometer was then cooled with a mixture of solid carbon dioxide and gasoline, or with commercial liquid ammonia until the pressure inside was less than atmospheric and by applying a heated 
glass rod the tip was broken carefully, so as to lose no glass by splintering. The picnometer was then evacuated several times, filled with dry air and weighed, as before, by two observers.

In the earlier determinations an attempt was made to obtain a check on the total mass of ammonia by absorbing it in an evacuated flask of concentrated sulphuric acid of known weight. For this operation a small steel tube was inclosed in rubber tubing connecting the picnometer and acid flask. Just enough length of rubber tubing was used to furnish the necessary flexibility for breaking the tip of the picnometer with the steel tube. Considerable difficulty was experienced in getting good, clean breaks. A small mercury manometer was sealed into the neck of the acid flask which served to indicate any leakage of air into the flask during the operation. From the observed increase in pressure, which was usually small, a correction was applied for the weight of this air leakage. The results obtained by this method were consistently lower by about I or $2 \mathrm{mg}$-that is, about I part in 2000 of the total mass - than those obtained by the method of direct weighing, which discrepency was probably due to the action of the ammonia on the rubber tubing. No weight was given in the final results to the mass determinations by this method because of the great uncertainty as to the action of the ammonia on the rubber.

In the later determinations the total mass of ammonia was measured before filling the picnometer, as well as after each series of measurements. For this purpose a small auxiliary tube was used which consisted of a graduated glass tube soldered to a steel needle valve by a method described in another communication from this laboratory. ${ }^{8}$ This auxiliary tube was evacuated and weighed, then filled with approximately the desired amount of ammonia and weighed again. The total mass determined in this manner agreed in each case, within better than I part in 10000 with that determined later by the direct weighing of the picnometer filled and empty. A different balance and a different set of weights were used for the two determinations.

\section{GENERAL DESCRIPTION OF APPARATUS}

\section{PICNOMETERS}

The picnometers used in these measurements were made from soda glass and annealed thoroughly. Capillary tubing of about 2 $\mathrm{mm}$ internal diameter and $3 \mathrm{~mm}$ wall thickness was selected with

McKelvy and Taylor, J. Am. Chem. Soc., 42, p. 1364; 2920. 
special attention to uniformity of bore. Scales were etched upon those capillary tubes by ruling divisions at intervals of I.5 mm with a dividing engine.

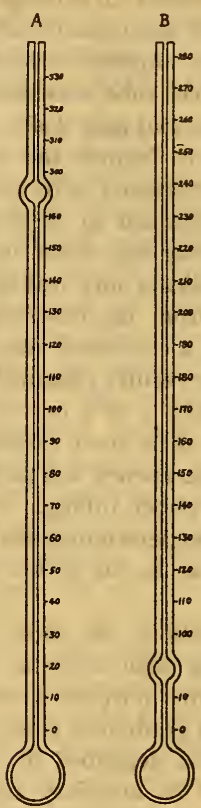

F1G. 2.-Sketch of picnometers, showing position of arbitrary scaling (Tables 6 and 7)

Picnometer A used for lower part of temperature range, with one check reading at high temperature; B for higher part of range with one check at a low temperature

Two types of picnometers were used (Fig. 2). Type A was used in the measurements considerably below room temperature, usually from o to $-50^{\circ} \mathrm{C}$. The small upper bulb served as an expansion reservoir for the ammonia when at room temperature. The volume of this upper bulb was so adjusted as to give a measurement at about $+40^{\circ} \mathrm{C}$ and thus afford a means of comparison with measurements in the other types. 
Similarly in type B, the short capillary between the two bulbs permitted one measurement at a low temperature for the purpose of comparison. This design proved to be very convenient in filling with approximately the desired amount of ammonia, which was accomplished by immersing the bulb in liquid ammonia exposed to the air and condensing just enough liquid to bring the meniscus into this short capillary. The upper capillary was of sufficient length to permit measurements over a range of about $50^{\circ} \mathrm{C}$.

\section{BALANCE AND WEIGHING CHAMBER}

The balance used in the calibrations of the picnometers and in the determinations of the mass of ammonia was made by $\mathrm{A}$. Collot, Paris. It was equipped with air dashpots to make the swings practically aperiodic. The picnometers were suspended in a closed chamber directly beneath the balance by means of small rods connected to the scale pans. Weighings could be made to about $0.1 \mathrm{mg}$. The weights used in all the weighings were calibrated by the weights and measures division of this Bureau and corrections given to o.or $\mathrm{mg}$.

\section{THERMOREGULATED BATH}

The thermoregulated bath used in all of the measurements consisted of a cylindrical Dewar vacuum flask of about 6 liters capacity. The temperature regulating mechanism was assembled as a unit in a long cylindrical brass tube about one-fourth the diameter of the flask, so as to leave more than three-fourths of the useful area available for introduction of the picnometers. This regulating unit included a motor-driven direct-connected screw propeller stirrer, an electric heating coil, a carbon dioxide expansion cooling coil, and a thermostat coil filled with toluene. A fixed contact in the thermostat head served to maintain the temperature constant to about $0.0 \mathrm{r}^{\circ}$. The details of the construction of a similar unit have been previously described. ${ }^{\circ}$ The liquid used in the bath for the temperature interval -50 to $+50^{\circ} \mathrm{C}$ was a mixture of about 65 per cent carbon tetrachloride and 35 per cent gasoline, a mixture selected with reference to fluidity and transparency at temperatures down to $-50^{\circ} \mathrm{C}$, combined with maximum safety from fire hazard when at room temperature or warmer. The volatile hydrocarbons which meet the greatest number of requirements

Osborne, B. S. Bull., 14, D. 145; x917 (Scientific Paper No. 301). 
of a low-temperature bath are not safe alone in proximity to electric motors and heating circuits which may possibly fail and spark but the admixture of a large carbon tetrachloride content makes the fluid entirely safe in this respect and does not destroy transparency to a serious degree, provided reasonable precautions are taken to exclude atmospheric moisture from getting dissolved in it and freezing out when cooled. The flash point was about $+50^{\circ} \mathrm{C}$. For temperatures in the interval +50 to $+100^{\circ} \mathrm{C}$ a high boiling point kerosene was used. As a protection from possible failure of the picnometers under pressure and also failure of the Dewer flask itself, the bath was inclosed in a metal case which was provided with celluloid windows about $3 \mathrm{~mm}$ in thickness.

\section{THERMOMETERS}

In the earlier measurements mercurial thermometers graduated in tenth-degrees were used over the temperature interval -30 to $+50^{\circ} \mathrm{C}$. These thermometers were calibrated against platinum resistance thermometers. Below $-30^{\circ} \mathrm{C}$ Baudin toluene thermometers were used in the first series, but were found to be unreliable to better than $0.1^{\circ}$, due to drainage. In the later measurements resistance thermometers were employed in this region and also at higher temperatures, together with mercurial thermometers. The Wheatstone bridge used in connection with the resistance thermometers was of the 4 -dial type and has been described previously. ${ }^{10}$

\section{CALIBRATION OF PICNOMETERS}

The volume per scale division of the capillaries in each picnometer was determined by the usual method of observing the lengths of a mercury thread of known mass. Threads of different lengths were used. A check on this value of the volume per scale division was obtained from the calibration at various divisions on the scale.

Distilled water and mercury, which hat been purified by the amode process and by distillation, were used in the volumetric calibrations. Volumes were determined by observing the level of the meniscus at a given temperature, usually $20^{\circ} \mathrm{C}$, weighing in air, and using the factor given in the Landolt and Börnstein tables of physical and chemical constants, which contain the

10 B. S. Bull., 13, p. 547; 1916 (Scientific Paper No. 288). 
buoyancy and specific volume corrections. ${ }^{11}$ Special precautions were taken in the calibrations with water to dry the walls of the capillary above. The portion of the picnometer filled with liquid was immersed in ice and the upper space evacuated to a pressure of about I mm.

Readings were taken upon the lower surface of the concave water meniscus and upon the upper surface of the convex mercury meniscus which, of course, introduced a systematic difference between the two calibrations. As an illustration of this, the initial calibration of picnometer $\mathrm{A}$ is given in Table 6.

TABLE 6.-Initial Calibration of Picnometer A

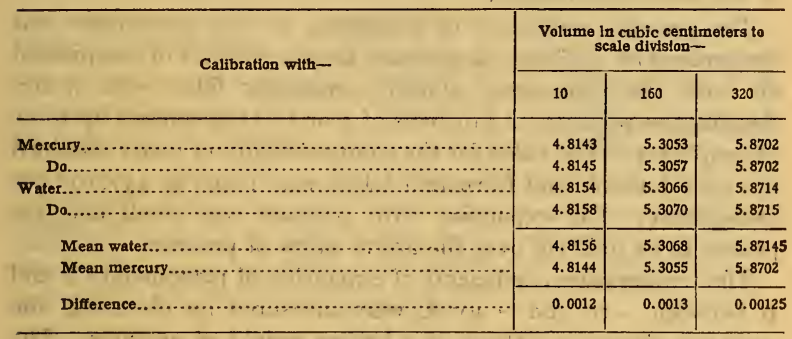

Assuming that the shapes of the water and mercury menisci are concave and convex hemispheres, respectively, in capillaries of the particular size used (about $2 \mathrm{~mm}$ in diameter), the difference in the volume determined by reading to any graduated mark is equal to the difference between the volume of a sphere and its circumscribed cylinder whose length and diameter are the diameter of the capillary. Numercially the difference is

$$
2 r\left(\pi r^{2}\right)-\frac{4}{3} \pi r^{3} \equiv \frac{2}{3} \pi r^{3},
$$

where $r$ is the radius of the capillary. The diameter of the capillary in the preceding illustration was found from the calibration to be r. $66 \mathrm{~mm}$, which gives for the calculated difference in volume 0.0012

${ }^{11}$ Although the Landolt-Börnstein tables are labeled cubic centimeters, the factor given actually reduces volumes to milliliters rather than to cubic centimeters, but the difference in the two units is insignificant for the results of work described in this paper. The volume of $\mathrm{Igg}$ of water at $4^{\circ} \mathrm{C}$, defined as $\mathrm{I}$ liter, is $1000.027 \mathrm{~cm}^{3}$, namely, differs from a cube of $10 \mathrm{~cm}$ edge by about 27 parts in $\mathrm{I} 000000$. The final results of this paper are carried to the point where $z$ or 2 parts in 10000 have significance; one more decimal place is retained in the intermediate stages-that is, volume measurements are recorded to I part in 50000 (20 parts in 1000000 ) - but the last figure is in doubt by considerably more than a single unit, and the distinction between milliliters and cubic centimeters for its expression may well be neglected. 
$\mathrm{cm}^{3}$. The results from several calibrations indicate that the above method of calculating the difference in volume between the two menisci is fairly reliable for capillaries of the particular dimensions used.

Since liquid ammonia wets the walls of the tube and has a meniscus similar to that of water, the desired volumes are obviously those determined by the calibrations with water. The calibrations with mercury, however, are probably the more accurate. The final volumes adopted were obtained from the mean of several mercury calibrations plus the calculated correction for the shape of the meniscus. These agreed well in most cases with the mean of the water calibrations.

The pressure coefficient of expansion of each picnometer was determined by applying air pressure from a cylinder of compressed air with the picnometer almost completely filled with water. Readings were taken at intervals of 5 or Io atmospheres up to 50 atmospheres. The value for the compressibility of water obtained from the Landolt and Börnstein tables was taken as $45 \times 10^{-6}$ per atmosphere. The expansion with pressure was small and appeared to be uniform over the above range of pressure.

The temperature coefficients of expansion of picnometers $\mathrm{A}$ and $\mathrm{B}$ between -20 and $+40^{\circ} \mathrm{C}$ were measured by observing the apparent change in volume of a known weight of mercury. The difference between the observed volume change and the expansion of the mercury (taken from Landolt and Börnstein physical tables) furnished an approximate value for the expansion coefficient of the glass. The results obtained by this method were inconsistent, the values for the temperature coefficient of cubical expansion varying from 0.000025 to 0.000028 per degree centigrade. The coefficient of linear expansion of a sample taken from picnometer B was determined by C. G. Peters of this Bureau, using a Fabry and Perot interferometer. He obtained the value $9.8 \times \mathrm{IO}^{-6}$. The temperature coefficient of cubical expansion used throughout the measurements here presented was based upon the above determination and taken as $2.9 \times \mathrm{IO}^{-5}$ per degree centigrade.

The final results of the picnometer calibrations are given in Table 7. The capillaries selected were found to be so uniform that application of the caliber corrections would not have changed any result by more than I part in ro ooo. Interpolation was effected by the use of the factors-volume per scale division. The initial calibration of $\mathrm{A}$ was used in the calculations of the first 
series of specific volume measurements (Table 8). In the process of filling $\mathrm{A}$ the second time a small crack developed in the capillary at about the I 40 scale division, probably caused by cooling too rapidly with liquid air. This crack was healed and the picnometer recalibrated after the second series of measurements. The lower bulb of A was accidentally broken in cleaning preparatory to filling the third time and a new one blown. The third calibration was made after the measurements of series 5 . The pressure coefficient of expansion of A with its new lower bulb was not determined, since measurements were taken only at low pressures.

TABLE 7.-Final Results of Picnometer Calibrations PICNOMETER A

\begin{tabular}{|c|c|c|c|c|c|c|c|}
\hline \multirow{2}{*}{ Date } & \multicolumn{4}{|c|}{$\begin{array}{l}\text { Volume in cubic centimeters to scale } \\
\text { division- }\end{array}$} & \multirow{2}{*}{$\begin{array}{l}\text { Volume } \\
\text { per scale } \\
\text { division } \\
\text { in cubic } \\
\text { centi- } \\
\text { meters }\end{array}$} & \multicolumn{2}{|c|}{$\begin{array}{l}\text { Increase in volume } \\
\text { per unit voiume }\end{array}$} \\
\hline & 10 & 130 & 160 & 300 & & $\begin{array}{c}\text { Per } \\
\text { atmos- } \\
\text { phere }\end{array}$ & $\begin{array}{l}\text { Per } \\
\text { degree } \\
\text { centi- } \\
\text { grade }\end{array}$ \\
\hline $7+1$ & & & $\overline{1}$ & & & & \\
\hline February, 1915..... & 4.8156 & ............. & 5.3067 & 5.8201 & 0.00327 & 0.000009 & 0.000029 \\
\hline March, 1916 ... & 4.8158 & 5. 2089 & 5.3008 & 5.9143 & .00327 & $\therefore$ & $\cdots$ \\
\hline Febraary, 1917 ................. & 6.1768 & 6.5699 & 6.6618 & 7.1743 & .00327 & $\because \ldots$ & \\
\hline
\end{tabular}

PICNOMETER $\mathbf{A}_{2}$

\begin{tabular}{|c|c|c|c|c|c|c|c|}
\hline$x^{9}, 10$ & 10 & 50 & 150 & 300 & 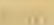 & & 160 \\
\hline May, $1920 \ldots \ldots \ldots \ldots \ldots \ldots \ldots$ & 4. 3593 & 4. 7065 & 5. 4007 & 6.3313 & .00694 & .000009 & .000029 \\
\hline
\end{tabular}

PICNOMETER A3

\begin{tabular}{l|r|r|r|r|r|r}
\hline July, 1918.................... & \multicolumn{1}{c|}{100} & 150 & 200 & 300 & \\
\cline { 2 - 3 } & 5.6205 & 5.8424 & 6.0642 & 6.3664 & .00444 & .000010 \\
\hline
\end{tabular}

PICNOMETER B

\begin{tabular}{|c|c|c|c|c|c|c|c|}
\hline 1) & 5 & 100 & 200 & 300 & 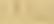 & 1 & \\
\hline December, 1915 ................ & 5.0112 & 5.6205 & 6.0642 & 6.5079 & .00444 & .000010 & .000029 \\
\hline May, $1920 \ldots \ldots \ldots \ldots \ldots . . . . . . .$. & 5.0113 & 5.6201 & 6.0644 & ......... & .00444 & ............. & .... \\
\hline
\end{tabular}

\section{PURIFICATION OF SAMPLES AND DESCRIPTION OF PICNOMETER FILLINGS}

The ammonia used in these measurements was prepared by McKelvy and Taylor of the chemical division of this Bureau, by four methods described more in detail in an independent paper. ${ }^{13}$

Is To be published later. 
Only a brief description of the processes of purification will therefore be given here.

METHOD I.-A commercial sample in which no traces of pyridine or ammonium acetate could be detected chemically and which showed a very small residue on evaporation was used as the starting material. This material was converted into ammonium sulphate by passing the gas into sulphuric acid after it had been passed through a tube containing lime heated to a red heat. The ammonium-sulphate solution obtained was heated with sodium hydroxide and the ammonia gas thus liberated. The gas was dried by passing it through an all-glass train of potassium hydroxide, ignited lime, and barium oxide, and was then condensed in a glass bulb cooled with a mixture of carbon dioxide and petroleum ether. The ammonia was then fractionally distilled several times, frozen with liquid air repeatedly, and then frozen by its own evaporation, the vapor being pumped off through a vacuum pump. The final products obtained by the above procedure are designated in Table 8 as samples $\mathrm{F}, \mathrm{G}$, and $\mathrm{H}$.

METHOD 2.-A sample of ammonia the same as the one used in method I was used as the starting material. This was transferred by distillation into a small steel container which would hold about a kilogram. The first portion was discarded and the middle portion was distilled into a similar vessel containing metallic sodium in the form of a fine wire to remove any traces of water. Following this dehydration the liquid was distilled into a high-pressure fractional-distillation apparatus and fractionally distilled 8 times, rejecting the first and last fractions (a little less than o.I the total volume of the liquid) in each distillation. The product thus obtained was distilled into a vacuum-fractional distillation apparatus of glass and fractionally distilled about ro times, the first and last portions being rejected in each case. The ammonia was then frozen in liquid air and the residual vapor and gas were pumped off. The ammonia was then allowed to warm up until it was entirely liquid and some of the vapor was escaping through a mercury seal. It was again frozen in liquid air and the vapor pumped off as before. This process was repeated several times. Finally the ammonia was frozen into small flocculent crystals by its own evaporation, the resulting vapor being pumped off and discarded. This final product, designated sample $\mathrm{L}$ in Table 8 , was used for filling the picnometers.

METHOD 3. -This method was the same as method 2, except that a sample of synthetic ammonia made by the Haber process 
was used as a starting material, instead of the sample previously described. This synthetic sample proved to be extremely pure except for a comparatively large amount of water, which was easily removed by means of the metallic sodium. The samples designated $I$ and $P$ in Table 8 were prepared by this method.

METHOD 4.-The procedure employed in this method was similar to that followed in method 2 , using the same source of ammonia, the dehydration with metallic sodium, and the highpressure fractional distillations. No vacuum fractional distillations were made. The sample designated $\mathrm{A}$ in Table 8 was prepared by this method.

The tests for purity on the final samples of ammonia obtained from the above methods gave the following results: Water, less than 0.003 per cent, by weight, which was the limit of sensitivity of the chemical test applied; noncondensing gases, from approximately I part in ro o0o to I part in I 000 ooo, by volume.

The picnometers were cleaned with a mixture of concentrated nitric and sulphuric acids, aqueous potassium hydroxide solution, and washed with distilled water. The upper ends of the picnometers were always constricted so as to facilitate satisfactory seals. They were then sealed directly into the glass line of the vacuum-distillation apparatus and evacuated to a pressure less than $0.00 \mathrm{rm}$ of mercury. After a sufficient quantity of the purified ammonia had been distilled into one of the picnometers, the supply reservoir was cut off by closing an intervening stopcock and the ammonia frozen by means of liquid air. The vapor phase was pumped off with the aid of a high-vacuum pump, and the picnometer was sealed by fusing the constricted capillary. The method of filling with approximately the desired amount varied somewhat. In most instances commercial liquid ammonia in an open Dewar flask was used as a cooling agent to condense the desired amount into the picnometers directly, or into a small graduated tube of known volume for transfer by distillation into the picnometers. A mixture of carbon dioxide and petroleum ether was sometimes used for cooling. In the last fillings, for the measurements at the higher temperatures, it was necessary to exercise particular care to fill within a few milligrams of the desired mass. For this purpose a small glass tube, soldered to a steel needle valve, was filled with a slight excess of ammonia and then small amounts were blown off through the valve. This method proved very convenient in adjusting to the required amount and also furnished an excellent check upon the mass 
determinations, since the auxiliary tube lent itself most readily to direct weighings.

\section{RESULTS OF MEASUREMENTS}

The results of all the measurements of the specific volume are collected in Table 8 . They have been divided into separate series, since each series consists of measurements with a particular sample, picnometer, and filling. The various factors which enter into the results have also been included.

TABLE 8.-Measurements of Specific Volume of Liquid Ammonia

SERIES 1

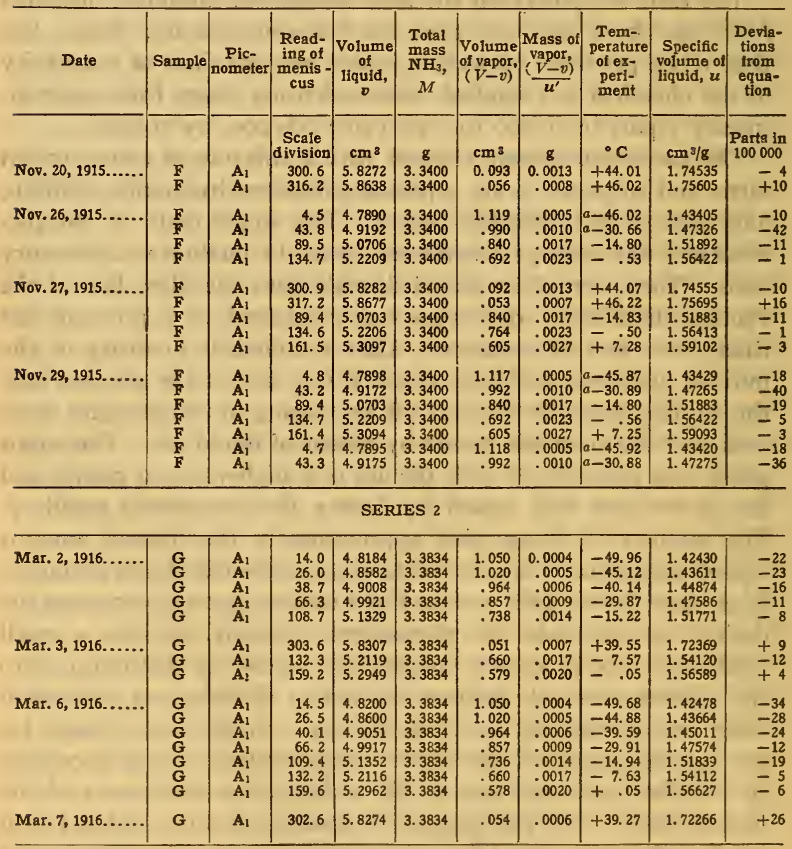

\footnotetext{
a Temperatures measured with toluene thermometers, uncertainty about $0 . x^{\circ} \mathrm{C}$.
} 
TABLE 8.-Measurements of Specific Volume of Liquid Ammonia-Continued

SERIES 3

\begin{tabular}{|c|c|c|c|c|c|c|c|c|c|c|}
\hline Date & Sample & $\begin{array}{c}\text { Plc- } \\
\text { nometer }\end{array}$ & $\begin{array}{l}\text { Read- } \\
\text { ing of } \\
\text { menis- } \\
\text { cus }\end{array}$ & $\begin{array}{c}\text { Volume } \\
\text { of } \\
\text { liquid, } \\
v\end{array}$ & $\begin{array}{c}\text { Total } \\
\text { mass } \\
\mathrm{NH}_{3} \\
M\end{array}$ & $\begin{array}{l}\text { Volume } \\
\text { of vapor, } \\
(V-v)\end{array}$ & $\begin{array}{c}\text { Mass of } \\
\text { vapo, } \\
\frac{(V-v)}{u^{\prime}}\end{array}$ & $\begin{array}{l}\text { Tem- } \\
\text { perature } \\
\text { of ex- } \\
\text { peri- } \\
\text { ment }\end{array}$ & $\begin{array}{l}\text { Specific } \\
\text { volume of } \\
\text { liquid, } u\end{array}$ & $\begin{array}{l}\text { Devia- } \\
\text { tions } \\
\text { from } \\
\text { equa- } \\
\text { tion }\end{array}$ \\
\hline & & & $\begin{array}{c}\text { Scale } \\
\text { diviston }\end{array}$ & $\mathrm{cm}^{3}$ & g & $\mathrm{cm}^{3}$ & 8 & ${ }^{\circ} \mathrm{C}$ & $\mathrm{cm}^{3} / \mathrm{g}$ & $\begin{array}{l}\text { Parts in } \\
\text { I00 } 000\end{array}$ \\
\hline Mar. 3, 1916. . & $\begin{array}{l}\mathbf{G} \\
\mathbf{G} \\
\mathbf{G} \\
\mathbf{G} \\
\mathbf{G} \\
\mathbf{G} \\
\mathbf{G} \\
\mathbf{G}\end{array}$ & $\begin{array}{l}\mathbf{B} \\
\mathbf{B} \\
\mathbf{B} \\
\mathbf{B} \\
\mathbf{B} \\
\mathbf{B} \\
\mathbf{B} \\
\mathbf{B}\end{array}$ & $\begin{array}{l}100.5 \\
120.2 \\
148.3 \\
178.7 \\
212.0 \\
247.4 \\
269.9 \\
291.0\end{array}$ & $\begin{array}{l}5.6184 \\
5.7071 \\
5.8336 \\
5.9701 \\
6.1200 \\
6.2796 \\
6.3805 \\
6.4747\end{array}$ & $\begin{array}{l}3.6476 \\
3.6476 \\
3.6476 \\
3.6476 \\
3.6476 \\
3.6476 \\
3.6476 \\
3.6476\end{array}$ & $\begin{array}{l}0.975 \\
.886 \\
.762 \\
.627 \\
.479 \\
.320 \\
.222 \\
.127\end{array}$ & $\begin{array}{l}0.0025 \\
.0031 \\
.0037 \\
.0042 \\
.0044 \\
.0041 \\
.0032 \\
.0020\end{array}$ & $\begin{array}{l}-7.57 \\
+\quad .05 \\
+10.00 \\
+20.01 \\
+29.98 \\
+39.56 \\
+45.09 \\
+49.90\end{array}$ & $\begin{array}{l}1.54135 \\
1.56595 \\
1.60093 \\
1.63861 \\
1.67984 \\
1.72351 \\
1.75077 \\
1.77603\end{array}$ & $\begin{array}{r}-2 \\
+8 \\
+7 \\
-4 \\
-6 \\
=5 \\
=6 \\
-2\end{array}$ \\
\hline Mar. 6, 1916...... & $\stackrel{G}{G}$ & $\begin{array}{l}\mathbf{B} \\
\mathbf{B}\end{array}$ & $\begin{array}{l}100.4 \\
120.4\end{array}$ & $\begin{array}{l}5.6180 \\
5.7079\end{array}$ & $\begin{array}{l}\text { 3. } 6476 \\
\text { 3. } 6476\end{array}$ & $\begin{array}{r}.975 \\
.886\end{array}$ & $\begin{array}{l}.0025 \\
.0031\end{array}$ & $\begin{array}{r}7.63 \\
+\quad .05\end{array}$ & $\begin{array}{l}1.54124 \\
1.56617\end{array}$ & +3 \\
\hline Mar. 7, 1916...... & $\begin{array}{l}\mathbf{G} \\
\mathbf{G} \\
\mathbf{G} \\
\mathbf{G} \\
\mathbf{G} \\
\mathbf{G}\end{array}$ & $\begin{array}{l}\mathbf{B} \\
\mathbf{B} \\
\mathbf{B} \\
\mathbf{B} \\
\mathbf{B} \\
\mathbf{B}\end{array}$ & $\begin{array}{l}246.5 \\
270.1 \\
290.5 \\
148.4 \\
179.4 \\
212.6\end{array}$ & $\begin{array}{l}6.2750 \\
6.3812 \\
6.4725 \\
5.8341 \\
5.9730 \\
6.1222\end{array}$ & $\begin{array}{l}3.6476 \\
\text { 3. } 6476 \\
3.6476 \\
\text { 3. } 6475 \\
\text { 3. } 6476 \\
\text { 3. } 6476\end{array}$ & $\begin{array}{l}.325 \\
.222 \\
.131 \\
.761 \\
.624 \\
.477\end{array}$ & $\begin{array}{l}.0040 \\
.0032 \\
.0021 \\
.0037 \\
.0042 \\
.0044\end{array}$ & $\begin{array}{l}+39.27 \\
+45.13 \\
+49.80 \\
+10.00 \\
+20.23 \\
+30.16\end{array}$ & $\begin{array}{l}1.72230 \\
1.75096 \\
1.77547 \\
1.60106 \\
1.63940 \\
1.68043\end{array}$ & $\begin{array}{l}+5 \\
-7 \\
+20 \\
+15 \\
-9 \\
-16\end{array}$ \\
\hline
\end{tabular}

SERIES 4

\begin{tabular}{|c|c|c|c|c|c|c|c|c|c|c|}
\hline Apr. 4, 1916....... & $\mathbf{A}$ & B & 6.4 & 5. 0077 & 3. 4951 & 1.500 & 0.0007 & -46.43 & 1. 43306 & -8 \\
\hline Apr. $6,1916 \ldots . .$. & $\begin{array}{l}\mathbf{A} \\
\mathbf{A} \\
\mathbf{A} \\
\mathbf{A} \\
\mathbf{A} \\
\mathbf{A}\end{array}$ & $\begin{array}{l}\mathbf{B} \\
\mathbf{B} \\
\mathbf{B} \\
\mathbf{B} \\
\mathbf{B} \\
\mathbf{B}\end{array}$ & $\begin{array}{l}100.7 \\
122.0 \\
154.3 \\
189.0 \\
203.4 \\
228.4\end{array}$ & $\begin{array}{l}5.6228 \\
5.7186 \\
5.8637 \\
6.0198 \\
6.1070 \\
6.1959\end{array}$ & $\begin{array}{l}\text { 3. } 4951 \\
\text { 3. } 4951 \\
\text { 3. } 4951 \\
\text { 3. } 4951 \\
\text { 3. } 4951 \\
\text { 3. } 4951\end{array}$ & $\begin{array}{l}.882 \\
.798 \\
.655 \\
.501 \\
.416 \\
.327\end{array}$ & $\begin{array}{l}.0047 \\
.0053 \\
.0059 \\
.0060 \\
.0058 \\
.0052\end{array}$ & $\begin{array}{l}+12.82 \\
+20.03 \\
+30.10 \\
+39.94 \\
+44.99 \\
+49.84\end{array}$ & $\begin{array}{l}1.61093 \\
1.63866 \\
1.68053 \\
1.72531 \\
1.75021 \\
1.77566\end{array}$ & $\begin{array}{l}-15 \\
-6 \\
+4 \\
-5 \\
-9 \\
-4\end{array}$ \\
\hline Apr. 8, 1916....... & $\begin{array}{l}\mathbf{A} \\
\mathbf{A} \\
\mathbf{A} \\
\mathbf{A}\end{array}$ & $\begin{array}{l}\mathbf{B} \\
\mathbf{B} \\
\mathbf{B} \\
\mathbf{B}\end{array}$ & $\begin{array}{r}9.9 \\
100.8 \\
122.4 \\
153.3\end{array}$ & $\begin{array}{l}5.0236 \\
5.6232 \\
5.7204 \\
5.8592\end{array}$ & $\begin{array}{l}3.4951 \\
\text { 3. } 4951 \\
3.4951 \\
\text { 3. } 4951\end{array}$ & $\begin{array}{r}1.483 \\
.882 \\
.796 \\
.660\end{array}$ & $\begin{array}{l}.0007 \\
.0047 \\
.0053 \\
.0059\end{array}$ & $\begin{array}{l}-44.62 \\
+12.87 \\
+20.18 \\
+29.87\end{array}$ & $\begin{array}{l}1.43761 \\
1.61104 \\
1.63917 \\
1.67924\end{array}$ & $\begin{array}{l}-4 \\
-19 \\
-10 \\
-14\end{array}$ \\
\hline Apr. 12, 1916..... & $\begin{array}{l}\mathbf{A} \\
\mathbf{A} \\
\mathbf{A}\end{array}$ & $\begin{array}{l}\mathbf{B} \\
\mathbf{B} \\
\mathbf{B}\end{array}$ & $\begin{array}{l}190.0 \\
209.6 \\
229.8\end{array}$ & $\begin{array}{l}6.0242 \\
6.1123 \\
6.2032\end{array}$ & $\begin{array}{l}\text { 3. } 4951 \\
\text { 3. } 4951 \\
\text { 3. } 4951\end{array}$ & $\begin{array}{r}.497 \\
.410 \\
.320\end{array}$ & $\begin{array}{l}.0060 \\
.0058 \\
.0051\end{array}$ & $\begin{array}{r}+40.21 \\
+45.28 \\
+50.17\end{array}$ & $\begin{array}{l}\text { 1. } 72658 \\
\text { 1. } 75176 \\
\text { 1. } 77742\end{array}$ & $\begin{array}{l}-7 \\
-5 \\
-4\end{array}$ \\
\hline
\end{tabular}

SERIES 5

\begin{tabular}{|c|c|c|c|c|c|c|c|c|c|c|}
\hline Feb. 12, 1917...... & $\begin{array}{l}\mathbf{H} \\
\mathbf{H}\end{array}$ & $\begin{array}{l}\mathbf{A}_{1} \\
\mathbf{A}_{1}\end{array}$ & $\begin{array}{r}68.6 \\
160.0\end{array}$ & $\begin{array}{l}6.3586 \\
6.6563\end{array}$ & $\begin{array}{l}\text { 4. } 3189 \\
4.3189\end{array}$ & $\begin{array}{r}0.962 \\
.668\end{array}$ & $\begin{array}{r}0.0010 \\
.0018\end{array}$ & $\begin{array}{r}-30.99 \\
-7.42\end{array}$ & $\begin{array}{l}1.47262 \\
1.45184\end{array}$ & $\begin{array}{l}-26 \\
-1\end{array}$ \\
\hline \multicolumn{11}{|c|}{ SERIES 6} \\
\hline Mar. 4, 1917...... & $\mathbf{H}$ & $\mathbf{B}$ & 104.5 & 5.6392 & 3.5234 & 1.022 & 0.0051 & +10.55 & 1. 60282 & 0 \\
\hline Apr. 4, 1917...... & $\mathbf{H}$ & $\begin{array}{l}\mathbf{B} \\
\mathbf{B}\end{array}$ & $\begin{array}{l}135.2 \\
219.2\end{array}$ & $\begin{array}{l}5.7775 \\
6.1550\end{array}$ & $\begin{array}{l}3.5234 \\
3.5234\end{array}$ & $\begin{array}{l}.886 \\
.514\end{array}$ & $\begin{array}{l}.0062 \\
.0071\end{array}$ & $\begin{array}{l}+21.00 \\
+44.92\end{array}$ & $\begin{array}{l}\text { 1. } 64264 \\
\text { 1. } 75042\end{array}$ & $\begin{array}{l}+2 \\
+22\end{array}$ \\
\hline
\end{tabular}

SERIES 7

\begin{tabular}{|c|c|c|c|c|c|c|c|c|c|c|}
\hline $\begin{array}{l}\text { May } 29,1917 \ldots \ldots \\
\text { June } 11,1917 \ldots \ldots\end{array}$ & I & $\begin{array}{l}\mathbf{B} \\
\mathbf{B}\end{array}$ & $\begin{array}{r}6.5 \\
120.0\end{array}$ & $\begin{array}{l}\text { 5. } 0085 \\
5.7102\end{array}$ & $\begin{array}{l}\text { 3. } 4908 \\
\text { 3. } 4908\end{array}$ & $\begin{array}{r}1.548 \\
.848\end{array}$ & $\begin{array}{r}0.0008 \\
.0057\end{array}$ & $\begin{array}{r}-45.58 \\
+19.98\end{array}$ & $\begin{array}{l}\text { 1. } 43510 \\
\text { 1. } 63869\end{array}$ & $\begin{array}{l}-13 \\
+8\end{array}$ \\
\hline
\end{tabular}

SERIES 8

\begin{tabular}{|c|c|c|c|c|c|c|c|c|c|c|}
\hline Aug. $11,1917 \ldots$. & $\begin{array}{l}\text { I } \\
\text { I } \\
\text { I } \\
\text { I }\end{array}$ & $\begin{array}{l}\mathbf{B} \\
\mathbf{B} \\
\mathbf{B} \\
\mathbf{B}\end{array}$ & $\begin{array}{r}1.1 \\
9.4 \\
106.6 \\
125.3\end{array}$ & $\begin{array}{l}\text { 4. } 9901 \\
5.0272 \\
5.6549 \\
5.7390\end{array}$ & $\begin{array}{l}\text { 3. } 2432 \\
\text { 3. } 2432 \\
\text { 3. } 2432 \\
\text { 3. } 2432\end{array}$ & $\begin{array}{r}1.541 \\
1.503 \\
.886 \\
.802\end{array}$ & $\begin{array}{r}0.0040 \\
.0045 \\
.0122 \\
.0127\end{array}$ & $\begin{array}{l}-7.84 \\
-4.18 \\
+44.97 \\
+49.94\end{array}$ & $\begin{array}{l}\text { 1. } 54054 \\
1.55223 \\
1.75020 \\
1.77650\end{array}$ & $\begin{array}{r}0 \\
0 \\
-4 \\
+13\end{array}$ \\
\hline
\end{tabular}


TABLE 8.-Measurements of Specific Volume of Liquid Ammonia-Continued SERIES 9

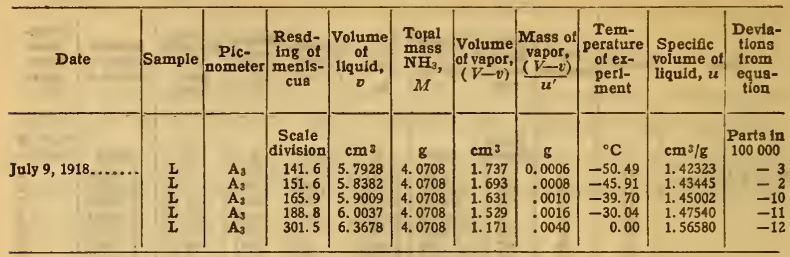

SERIES 10

\begin{tabular}{|c|c|c|c|c|c|c|c|c|c|c|}
\hline $\begin{array}{l}\text { May } 11,1920 \ldots \ldots \\
\text { May } 12,1920 \ldots . .\end{array}$ & $\begin{array}{l}\mathbf{P} \\
\mathbf{p} \\
\mathbf{P} \\
\mathbf{P} \\
\mathbf{P}\end{array}$ & $\begin{array}{l}\mathbf{B} \\
\mathbf{B} \\
\mathbf{B} \\
\mathbf{B} \\
\mathbf{B}\end{array}$ & $\begin{array}{r}6.5 \\
100.2 \\
167.0 \\
206.5 \\
240.4\end{array}$ & $\begin{array}{l}5.0227 \\
5.6333 \\
5.9328 \\
6.1097 \\
6.2617\end{array}$ & $\begin{array}{l}2.8665 \\
2.8665 \\
2.8665 \\
2.8665 \\
2.8665\end{array}$ & $\begin{array}{r}1.352 \\
.748 \\
.452 \\
.276 \\
.125\end{array}$ & $\begin{array}{r}0.0198 \\
.0255 \\
.0201 \\
.0139 \\
.0069\end{array}$ & $\begin{array}{r}+47.64 \\
+80.58 \\
+91.24 \\
+96.27 \\
+100.05\end{array}$ & $\begin{array}{l}1.76439 \\
1.98286 \\
2.08432 \\
\text { 2. } 14181 \\
2.18971\end{array}$ & $\begin{array}{l}+19 \\
+29 \\
+26 \\
+40 \\
+24\end{array}$ \\
\hline
\end{tabular}

SERIES 11

\begin{tabular}{|c|c|c|c|c|c|c|c|c|c|c|}
\hline $\begin{array}{l}\text { May } 11,1920 \ldots . \\
\text { May } 13,1920 \ldots .\end{array}$ & $\begin{array}{l}\mathbf{P} \\
\mathbf{P} \\
\mathbf{P} \\
\mathbf{P}\end{array}$ & $\begin{array}{l}\mathbf{A}_{2} \\
\mathbf{A}_{2} \\
\mathbf{A}_{2} \\
\mathbf{A}_{2}\end{array}$ & $\begin{array}{r}301.6 \\
311.2 \\
152.6 \\
52.6\end{array}$ & $\begin{array}{l}\text { 6. } 3515 \\
6.4186 \\
5.4159 \\
4.7111\end{array}$ & $\begin{array}{l}3.4625 \\
3.4625 \\
3.4625 \\
3.4625\end{array}$ & $\begin{array}{r}0.105 \\
.039 \\
1.029 \\
1.716\end{array}$ & $\begin{array}{l}0.0022 \\
.0009 \\
.0036 \\
.0001\end{array}$ & $\begin{array}{l}+60.22 \\
+63.22 \\
-\quad .03 \\
-78.59\end{array}$ & $\begin{array}{l}1.83553 \\
1.85423 \\
1.56579 \\
1.36065\end{array}$ & $\begin{array}{l}+6 \\
-3 \\
-8 \\
+3\end{array}$ \\
\hline
\end{tabular}

In the temperature interval -50 to $+50^{\circ} \mathrm{C}$ the values for the specific volume of the saturated vapor which enter into the correction for the mass of the vapor were based upon preliminary measurements made at this Bureau, the final results of which will be published in a separate paper. In the interval +50 to $+100^{\circ} \mathrm{C}$, the vapor specific volumes were obtained by extrapolation of the mean diameter of the temperature-density dome (often called the Cailletet and Mathias rectilinear diameter), Fig. 3. This diameter was found to be represented accurately by a second degree equation.

The scale of temperature used in these measurements is the scale defined by the resistance thermometer of pure platinum, calibrated in ice, steam, and sulphur vapor $\left(444.6^{\circ} \mathrm{C}\right.$ taken as the normal boiling point of sulphur). Using the Callender equation

$$
t=\frac{R_{\mathrm{t}}-R_{\mathrm{o}}}{R_{100}-R_{\mathrm{o}}} 100+\delta\left(\frac{t}{\mathrm{IOO}}-\mathrm{I}\right) \frac{t}{\mathrm{IOO}}
$$

as an interpolation equation, the temperature scale so defined represents the centigrade thermodynamic scale in the interval -50 to $450^{\circ} \mathrm{C}$ to the accuracy with which that scale is at present known, and has been adopted as the standard working scale of 
this Bureau in that interval. By direct comparison of several platinum resistance thermometers with a constant-volume hydrogen thermometer at temperatures below $-50^{\circ} \mathrm{C}$, Henning ${ }^{13}$ found the corrections necessary to reduce to the gas scale the temperatures determined with the above equation. From Henning's results a correction of $+0.08^{\circ}$ has been applied to the measurement at $-78.59^{\circ} \mathrm{C}$

\section{TEMPERATURE-DENSITY DOME (NH3)}

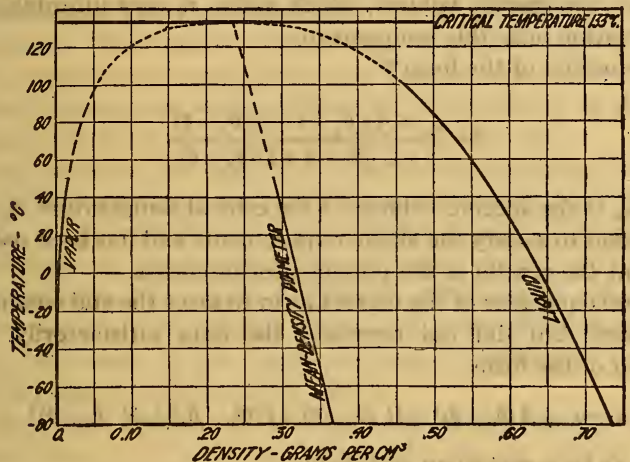

FIG. 3.-Density of ammonia at various temperatures

The arithmetical average of the liquid density and vapor density at given temperature locates the abscissa of the mean density diameter for that temperature

Solid lines are located from experimental measurements, dash lines by extrapolation of the diameter. The dotted top of the dome is shaped in accordance with the requirement of meeting the critical temperature line as a tangent at the point of its intersection with the mean diameter. As drawn, it agrees with measurements by Berthoud

\section{FORM OF EMPIRICAL EQUATION TO REPRESENT SPECIFIC VOLUME OF LIQUID AMMONIA AS A FUNC- TION OF TEMPERATURE}

A form of empirical equation was sought which would represent the experimental results closely and which would also satisfy the terminal conditions at the critical temperature. To be consistent with our present knowledge of the behavior of substances at the critical temperature, $\theta_{c}$, the equation should give a finite value for the specific volume, $u$. and for the derivative $\frac{d u}{d \theta}$ should give a value of $+\infty$.

\footnotetext{
18 Ann. d. Phys., (4), p. 653: 19:3.
} 
The Avenarius ${ }^{14}$ equation,

$$
u=A+B \log \left(\theta_{c}-\theta\right),
$$

has frequently been used to express the volume of the liquid as a function of temperature. Using the constants $A=3.68, B=\mathrm{I}$, and $\theta_{\mathrm{c}}=\mathrm{r} 3 \mathrm{O}$, this equation was found to represent the experimental results in the range -50 to $50^{\circ} \mathrm{C}$ remarkably well. How ever, at the critical temperature this equation gives an infinite value for the specific volume, which makes it very unsuitable for extrapolation near this temperature.

An equation of the form ${ }^{15}$

$$
u=\frac{u_{\mathrm{c}}+A \sqrt{\theta_{c}-\theta}+B\left(\theta_{c}-\theta\right)}{\mathrm{I}+C \sqrt{\theta_{\mathrm{c}}-\theta}+D\left(\theta_{c}-\theta\right)}
$$

where $u_{\mathrm{c}}$ is the specific volume at the critical temperature, $\theta_{\mathrm{c}}$, has been found to satisfy the above requirements and has been used to represent the results of the present measurements.

Several equations of the correct form to meet the end conditions were tried, but did not represent the data satisfactorily. An equation of the form

$$
u=u_{\mathrm{o}}+A\left(\theta_{\mathrm{c}}-\theta\right)^{\frac{3}{3}}+B\left(\theta_{\mathrm{o}}-\theta\right)+C\left(\theta_{\mathrm{o}}-\theta\right)^{\frac{3}{3}}+D\left(\theta_{\mathrm{o}}-\theta\right)^{2}
$$

proved to be surprisingly unsuitable.

14 Kiewsche universitätsnachrichten, 6, p. 249; 1884 (reference taken from Goodenough and Mosher).

2s This equation is entirely empirical in that it is based on purely empirical relations. The selection of the particular form was not, however, pure guesswork, a rational development leading to its trial. The Cailletet and Mathias relation for the mean diameter of the temperature-density dome is that of a linear equation between mean density and temperature. Preliminary data obtained for the specific volumes of both the vapor and liquid phases showed that the mean diameter is not strictly linear, but is more exactly ex. pressed by the empirical relation (where $\rho=$ densities; where $\theta=$ temperatures):

$$
\frac{\rho+\rho^{\prime}}{2}=\rho_{0}+A \sqrt{\theta_{0}-\theta}+B\left(\theta_{0}-\theta\right) \text {. }
$$

A well-known relation for expressing approximately the vapor pressure of ammonia as a function of temperature is:

$$
\log p=A^{\prime}+\frac{B^{\prime}}{\theta} \text {. }
$$

Osborne and Van Dusen (footnote $x$ ) found the relation between latent heat of vaporization and temperature to be expressed very closely by the empirical equation:

$$
L=A^{\prime \prime} \sqrt{\theta_{0}-\theta}+B^{\prime \prime}\left(\theta_{0}-\theta\right) .
$$

Assuming the gas law to hold for saturated vapor $(p=R \rho \theta)$, and using the Clapyron equation to eliminate latent heat, the acceptance of the validity of the empirical relations $(x)$ and $(3)$ transforms $(x)$ into the form given in the text of the paper. The justification of the form rests not on the above derivation but solely on the test of applying it to the data obtained in the measurements described in this paper. This test is discussed in the text of the succeeding sections. 


\section{DISCUSSION OF RESULTS}

The results of the measurements may be expressed by means of the following empirical equation:

$$
u=\frac{4.2830+0.813055 \sqrt{133-\theta}-0.0082861(133-\theta)}{\mathrm{I}+0.424805 \sqrt{\mathrm{I} 33-\theta}+0.015938(\mathrm{I} 33-\theta)},
$$

where the positive values of the square roots are to be used. The units for $\theta$ are degrees centigrade, and for $u$, cubic centimeters per gram. The value for the critical temperature is based upon the experimental determination by Cardoso and Giltay. ${ }^{16}$ The critical volume was obtained from the extrapolation of the mean diameter of the temperature-density dome (Fig. 3).

The deviations, in parts in 100000 , of the individual measurements from values computed by the above equation are shown in Table 7. It may be noted that nearly all of the measurements were made in the temperature interval -50 to $+50^{\circ} \mathrm{C}$. The last two series were made in order to establish the trend of the curve outside of this range. In each of these series one measurement was made in the range previously investigated to permit of comparison with the earlier series.

Since the empirical equation expresses closely the experimental results from -78 to $+100^{\circ} \mathrm{C}$ and also fits the critical volume as determined by the generally accepted method, it is believed that the interpolated values between +100 and $+133^{\circ} \mathrm{C}$ are a fair approximation to the volumes of the liquid in this region. Values computed from this equation for every degree between the freezing point and the critical temperature, in both metric and English units, are given in the appendix.

An estimate of the accuracy of the measurements may be obtained by assigning average and maximum errors to each element which enters into the final result. Table 9 contains a tabulation of the magnitude of these errors which were estimated from the experience gained in making the measurements. They apply more particularly to the temperature range, -50 to $+50^{\circ} \mathrm{C}$.

16 Arch. Sci. Phys. Nat, Genève, 84, p. 20; 1912. 
TABLE 9.-Estimation of Errors

[All errors are parts in 100000 produced in the final reault $u$ ]

\begin{tabular}{|c|c|c|c|}
\hline Source of error & Nature of error & $\begin{array}{c}\text { Average } \\
\text { error }\end{array}$ & $\underset{\text { error }}{\text { Marimum }}$ \\
\hline Caltbration of picnometer. . & Systematic............. & 4 & 15 \\
\hline Reading of meniscus............. & Accidental.............. & 6 & 15 \\
\hline Total mass of ammonta. . ....... & .....do.............. & 7 & 25 \\
\hline Volume of vapor.......................... & ............................. & 1 & 5 \\
\hline Specific volume of vapor............... & Systematic............ & 3 & 10 \\
\hline Measurement of temperature................................. & Accidental. ............. & 4 & 10 \\
\hline Total estimated........................ & $\begin{array}{l}\text { Systematic and acci- } \\
\text { dental. }\end{array}$ & 7 & 80 \\
\hline Observed deviations from empirical equation.. & .....do................... & 11 & 42 \\
\hline
\end{tabular}

The fair agreement between the observed and estimated average error indicates that the precision attained in the measurements was about that to be expected from the precision of the various factors. The observed maximum error is less than the estimated, which means that all of the possible errors of the same sign were never present in any single measurement.

In the above discussion no mention has been made of the possible systematic error introduced in any given series by the sample itself. From the above analysis the observed errors may easily be attributed to errors of observation. This leads to the important conclusion that the seven different samples of ammonia made by four different methods of purification yield results for the specific volume of the saturated liquid which are in agreement within the precision of the measurement.

The measurements described in this paper were made with very pure samples of ammonia. The question immediately arises in the practical application of the results as to how much the results would be affected by the impurities commonly found in commercial samples. Tests ${ }^{17}$ made at this Bureau upon eight standard American brands of commercial ammonia, which are believed to represent fairly well the material now used in the refrigeration industries, indicate that most commercial brands of ammonia contain less than o.I per cent of impurities. The nature of the impurities and the quantity of each present were not widely different in all eight brands, and it seemed that for the purpose in view any one might properly be taken as a fair representative of commercial ammonia and that no need existed for comparing each sample with chemically pure ammonia. A sample designated as

${ }^{17}$ McKelvy and Taylor, J. Am. Soc. Refrigeration Engineers, 8, No. 5, D. 45; 1917. 
$B$ in a previous analysis ${ }^{18}$ was used for three determinations of density at $+25^{\circ} \mathrm{C}$ in a glass picnometer of about $125 \mathrm{~cm}^{3}$ capacity. A separate filling was made for each determination. The mean of the three measurements agreed with the results on the highly purified ammonia within I part in 3000 . It seems reasonably certain that the density tables appended to this paper, representing values for pure ammonia, can be applied with an error well within I part in rooo to usual commercial ammonias of 99.9 per cent purity. In carrying the accuracy of this work on pure ammonia much beyond the needs of engineering practice due regard was had for the general desirability of accurate values of physical constants for pure substances and for the fact that extreme accuracy of measurement on the liquid phase was essential to securing a high enough accuracy of measurement on the vapor phase, by the methods used, to meet the needs of industrial refrigeration engineering, $I$ or 2 per cent in some parts of the temperature range.

Credit is due to G. F. O'Conner, who assisted in making many of the measurements.

\section{SUMMARY}

The results of previous measurements of the specific volume of saturated liquid ammonia are discussed briefly and compared with the authors' results.

Four glass picnometers of about $5 \mathrm{~cm}^{3}$ capacity were calibrated with water and mercury to an accuracy of a few parts in 100000. The temperature coefficient of expansion of the glass was obtained from a determination with an interferometer of the coefficient of linear expansion. The expansion of the picnometers with pressure was determined experimentally, using a liquid of known compressibility.

Seven samples of ammonia, purified by four somewhat different methods, were used in these picnometers, and volume measurements made throughout the temperature interval -78 to $+100^{\circ} \mathrm{C}$. Special tests' showed less than I part in Io 000 , by volume, of noncondensing gases present and less than o.or per cent, by weight, of other impurities.

The picnometers, after being partially filled with liquid ammonia, were immersed in a thermoregulated bath, the temperature of which could be maintained constant to about $0{ }^{\circ}$ OI C. Readings at various temperatures were then taken of the position of the ammonia meniscus in the calibrated capillary of the picnometer. 
Readings were taken at five-minute intervals for a period of about one-half hour in order to insure equilibrium.

The total mass of ammonia in each picnometer during any series of measurements was always determined afterwards by weighing the picnometer filled with ammonia, then breaking the tip and reweighing filled with dry air. In the later series the total mass was also determined before filling the picnometers, using a small auxiliary bulb soldered to a steel valve. The mass so determined agreed with the subsequent determination to better than $\mathrm{I}$ part in ro ooo.

The picnometers were so designed as to make the mass of the vapor phase small in comparison with the total mass of ammonia. The values for the specific volume of the saturated vapor which enter as a correction term were obtained from preliminary measurements made at this Bureau. In the interval +50 to $+100^{\circ} \mathrm{C}$ these values were obtained by extrapolating the mean diameter of the temperature-density dome.

An empirical equation was found which represents closely the results in the temperature range covered experimentally and also conforms to what is known about the behavior of liquids at the critical temperature. The average deviation of all the measurements from this equation is $\mathrm{x}$ part in $\mathrm{ro} 000$ and the maximum deviation is 4 parts in ro ooo.

As a final result the specific volume of saturated liquid ammonia is expressed by the equation:

$$
u=\frac{4.2830+0.813055 \sqrt{\mathrm{r} 33-\theta}-0.008286 \mathrm{I}(\mathrm{1} 33-\theta)}{\mathrm{I}+0.424805 \sqrt{\mathrm{r} 33-\theta}+0.015938(\mathrm{I} 33-\theta)},
$$

where $u$ is expressed in cubic centimeters per gram and $\theta$ in degrees centigrade.

WASHINGTON, October 8, 1920. 
APPENDIX.-TABLES OF SPECIFIC VOLUME AND DENSITY OF LIQUID AMMONIA UNDER SATURATION PRESSURE IN METRIC AND ENGLISH UNITS

Specific Volume of Liquid Ammonia under Saturation Pressure, in Cubic Centimeters per Gram

\begin{tabular}{|c|c|c|c|c|c|c|c|c|c|c|}
\hline${ }^{\circ} \mathrm{C}$ & $0^{\circ}$ & $1^{\circ}$ & $2^{\circ}$ & $3^{\circ}$ & $4^{\circ}$ & $5^{\circ}$ & $6^{\circ}$ & $7^{\circ}$ & $8^{\circ}$ & $9^{\circ}$ \\
\hline $\begin{array}{l}-70 \ldots \\
-60 \ldots \\
-50 . . \\
-40 . \\
-30 .\end{array}$ & $\begin{array}{l}1.3788 \\
1.4010 \\
1.4245 \\
1.4493 \\
1.4757\end{array}$ & $\begin{array}{l}1.3766 \\
1.3988 \\
1.4221 \\
1.4468 \\
1.4730\end{array}$ & $\begin{array}{l}1.3745 \\
1.3965 \\
1.4197 \\
1.4442 \\
1.4703\end{array}$ & $\begin{array}{l}1.3724 \\
1.3942 \\
1.4173 \\
1.4417 \\
1.4676\end{array}$ & $\begin{array}{l}1.3702 \\
1.3920 \\
1.4150 \\
1.4392 \\
1.4649\end{array}$ & $\begin{array}{l}1.3681 \\
1.3898 \\
1.4126 \\
1.4367 \\
1.4623\end{array}$ & $\begin{array}{l}1.3660 \\
1.3876 \\
1.4103 \\
1.4342 \\
1.4597\end{array}$ & $\begin{array}{l}1.3639 \\
1.3854 \\
1.4079 \\
1.4318 \\
1.4571\end{array}$ & $\begin{array}{l}1.3618 \\
1.3832 \\
1.4056 \\
1.4293 \\
1.4545\end{array}$ & $\begin{array}{l}1.3597 \\
1.3810 \\
1.4033 \\
1.4269 \\
1.4519\end{array}$ \\
\hline $\begin{array}{r}-20 . \\
-10 . \\
-0 . \\
+0 . \\
10 .\end{array}$ & $\begin{array}{l}1.5037 \\
1.5338 \\
1.5660 \\
1.5660 \\
1.6008\end{array}$ & $\begin{array}{l}1.5008 \\
1.5307 \\
1.5627 \\
1.5694 \\
1.6045\end{array}$ & $\begin{array}{l}1.4980 \\
1.5276 \\
1.5594 \\
1.5727 \\
1.6081\end{array}$ & $\begin{array}{l}1.4951 \\
1.5245 \\
1.5561 \\
1.5761 \\
1.6118\end{array}$ & $\begin{array}{l}1.4923 \\
1.5215 \\
1.5528 \\
1.5796 \\
1.6156\end{array}$ & $\begin{array}{l}1.4895 \\
1.5185 \\
1.5496 \\
1.5831 \\
1.6193\end{array}$ & $\begin{array}{l}1.4867 \\
1.5155 \\
1.5464 \\
1.5866 \\
1.6231\end{array}$ & $\begin{array}{l}1.4839 \\
1.5125 \\
1.5432 \\
1.5901 \\
1.6270\end{array}$ & $\begin{array}{l}1.4811 \\
1.5096 \\
1.5400 \\
1.5936 \\
1.6308\end{array}$ & $\begin{array}{l}1.4784 \\
1.5066 \\
1.5369 \\
1.5972 \\
1.6347\end{array}$ \\
\hline $\begin{array}{l}20 \ldots \\
30 \ldots \\
40 \ldots \\
50 \ldots \\
60 \ldots\end{array}$ & $\begin{array}{l}1.6386 \\
1.6800 \\
1.7257 \\
1.7766 \\
1.8341\end{array}$ & $\begin{array}{l}1.6426 \\
1.6844 \\
1.7305 \\
1.7820 \\
1.8403\end{array}$ & $\begin{array}{l}1.6466 \\
1.6888 \\
1.7354 \\
1.7875 \\
1.8465\end{array}$ & $\begin{array}{l}1.6506 \\
1.6932 \\
1.7404 \\
1.7931 \\
1.8529\end{array}$ & $\begin{array}{l}1.6547 \\
1.6977 \\
1.7454 \\
1.7987 \\
1.8593\end{array}$ & $\begin{array}{l}1.6588 \\
1.7023 \\
1.7504 \\
1.8044 \\
1.8658\end{array}$ & $\begin{array}{l}1.6630 \\
1.7069 \\
1.7555 \\
1.8102 \\
1.8725\end{array}$ & $\begin{array}{l}1.6672 \\
1.7115 \\
1.7607 \\
1.8160 \\
1.8792\end{array}$ & $\begin{array}{l}1.6714 \\
1.7162 \\
1.7659 \\
1.8220 \\
1.8860\end{array}$ & $\begin{array}{l}1.6757 \\
1.7209 \\
1.7713 \\
1.8280 \\
1.8930\end{array}$ \\
\hline $\begin{array}{l}70 . \\
80 . \\
90 . \\
100 .\end{array}$ & $\begin{array}{l}1.9000 \\
1.9774 \\
2.0708 \\
2.1885\end{array}$ & $\begin{array}{r}1.9072 \\
1.9859 \\
2.0813 \\
\end{array}$ & $\begin{array}{r}1.9145 \\
1.9946 \\
2.0920 \\
\ldots \ldots . . .\end{array}$ & $\begin{array}{r}1.9219 \\
2.0034 \\
2.1030 \\
\end{array}$ & $\begin{array}{r}1.9294 \\
2.0124 \\
2.1143 \\
\end{array}$ & $\begin{array}{l}1.9370 \\
2.0217 \\
2.1258 \\
2.261\end{array}$ & $\begin{array}{r}1.9448 \\
2.0311 \\
2.1377 \\
.\end{array}$ & $\begin{array}{r}1.9528 \\
2.0407 \\
2.1498 \\
\ldots . . .\end{array}$ & $\begin{array}{r}1.9608 \\
2.0505 \\
2.1623\end{array}$ & $\begin{array}{l}1.9690 \\
2.0605 \\
2.1752\end{array}$ \\
\hline & $\begin{array}{l}2.1885 \\
2.348\end{array}$ & $\cdots$ & $\ldots$ & . & $\ldots$ & $\begin{array}{l}2.261 \\
2.455\end{array}$ & … & .. & & •....... \\
\hline $\begin{array}{l}120 . \\
130 .\end{array}$ & $\begin{array}{l}2.50 \\
3.18\end{array}$ & & & $a 4.283$ & & 2.80 & & & & \\
\hline
\end{tabular}

Density of Liquid Ammonia under Saturation Pressure, in Grams per Cubic Centimeter

\begin{tabular}{|c|c|c|c|c|c|c|c|c|c|c|}
\hline${ }^{\circ} \mathrm{C}$ & $0^{\circ}$ & $1^{\circ}$ & $2^{\bullet}$ & $3^{\circ}$ & $4^{\circ}$ & $5^{\circ}$ & $6^{\circ}$ & $7^{\circ}$ & $8^{\circ}$ & $9^{\circ}$ \\
\hline 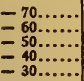 & $\begin{array}{r}0.7253 \\
.7138 \\
.7020 \\
.6900 \\
.6777\end{array}$ & $\begin{array}{r}0.7264 \\
.7149 \\
.7032 \\
.6912 \\
.6789\end{array}$ & $\begin{array}{r}0.7275 \\
.7161 \\
.7044 \\
.6924 \\
.6801\end{array}$ & $\begin{array}{r}0.7287 \\
.7172 \\
.7056 \\
.6936 \\
.6814\end{array}$ & $\begin{array}{r}0.7298 \\
.7184 \\
.7067 \\
.6948 \\
.6826\end{array}$ & $\begin{array}{r}0.7309 \\
.7195 \\
.7079 \\
.6960 \\
.6839\end{array}$ & $\begin{array}{r}0.7321 \\
.7207 \\
.7091 \\
.6972 \\
.6851\end{array}$ & $\begin{array}{r}0.7332 \\
.7218 \\
.7103 \\
.6984 \\
.6863\end{array}$ & $\begin{array}{r}0.7343 \\
.7230 \\
.7114 \\
.6996 \\
.6875\end{array}$ & $\begin{array}{r}0.7354 \\
.7241 \\
.7126 \\
.7008 \\
.6888\end{array}$ \\
\hline 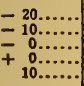 & $\begin{array}{l}.6650 \\
.6520 \\
.6386 \\
.6386 \\
.6247\end{array}$ & $\begin{array}{l}.6663 \\
.6533 \\
.6399 \\
.6372 \\
.6233\end{array}$ & $\begin{array}{l}.6676 \\
.6546 \\
.6413 \\
.6358 \\
.6218\end{array}$ & $\begin{array}{l}.6688 \\
.6559 \\
.6426 \\
.6345 \\
.6204\end{array}$ & $\begin{array}{l}.6701 \\
.6572 \\
.6440 \\
.6331 \\
.6190\end{array}$ & $\begin{array}{l}.6714 \\
.6585 \\
.6453 \\
.6317 \\
.6175\end{array}$ & $\begin{array}{l}.6726 \\
.6598 \\
.6467 \\
.6303 \\
.6161\end{array}$ & $\begin{array}{l}.6739 \\
.6611 \\
.6480 \\
.6289 \\
.6146\end{array}$ & $\begin{array}{l}.6752 \\
.6624 \\
.6493 \\
.6275 \\
.6132\end{array}$ & $\begin{array}{l}.6764 \\
.6637 \\
.6507 \\
.6261 \\
.6117\end{array}$ \\
\hline $\begin{array}{l}20 \ldots \ldots \\
30 \ldots \ldots \\
40 \ldots \ldots \\
50 \ldots \ldots \\
60 \ldots \ldots\end{array}$ & $\begin{array}{l}.6103 \\
.5952 \\
.5795 \\
.5629 \\
.5452\end{array}$ & $\begin{array}{l}.6088 \\
.5037 \\
.5779 \\
.5612 \\
.5434\end{array}$ & $\begin{array}{l}.6073 \\
.5921 \\
.5762 \\
.5594 \\
.5416\end{array}$ & $\begin{array}{l}.6058 \\
.5906 \\
.5746 \\
.5577 \\
.5397\end{array}$ & $\begin{array}{l}.6043 \\
.5890 \\
.5729 \\
.5560 \\
.5378\end{array}$ & $\begin{array}{l}.6028 \\
.5875 \\
.5713 \\
.5542 \\
.5359\end{array}$ & $\begin{array}{l}.6013 \\
.5859 \\
.5696 \\
.5524 \\
.5341\end{array}$ & $\begin{array}{r}.5998 \\
.5843 \\
.5680 \\
.5507 \\
.5321\end{array}$ & $\begin{array}{r}.5983 \\
.5827 \\
.5663 \\
.5489 \\
.5302\end{array}$ & $\begin{array}{l}.5968 \\
.5811 \\
.5646 \\
.5471 \\
.5283\end{array}$ \\
\hline $\begin{array}{r}70 \ldots \ldots \\
80 \ldots \ldots \\
90 \ldots \ldots \\
100 \ldots \ldots\end{array}$ & $\begin{array}{l}.5263 \\
.5057 \\
.4829 \\
.4569 \\
.426\end{array}$ & $\begin{array}{l}.5243 \\
.5036 \\
.4805 \\
.4541\end{array}$ & $\begin{array}{l}.5223 \\
.5014 \\
.4780 \\
.4512\end{array}$ & $\begin{array}{l}.5203 \\
.4991 \\
.4755 \\
.4483\end{array}$ & $\begin{array}{r}.5183 \\
.4969 \\
.4730 \\
.4453\end{array}$ & $\begin{array}{l}.5163 \\
.4946 \\
.4704 \\
.4422 \\
.407\end{array}$ & $\begin{array}{r}.5142 \\
.4924 \\
.4678 \\
.4391\end{array}$ & $\begin{array}{r}.5121 \\
.4900 \\
.4652 \\
.4360\end{array}$ & $\begin{array}{l}.5100 \\
.4877 \\
.4625 \\
.4327\end{array}$ & $\begin{array}{l}.5079 \\
.4853 \\
.4597 \\
.4294\end{array}$ \\
\hline $\begin{array}{l}120 \ldots \ldots \\
130 \ldots \ldots\end{array}$ & $\begin{array}{r}.420 \\
.385 \\
.315\end{array}$ & & & $a .2335$ & & .357 & ............. & & & $\because$. \\
\hline
\end{tabular}

a Critical. 
Specific Volume of Liquid Ammonia under Saturation Pressure, in Cubic Feet per Pound

[1 $\mathrm{ft}^{3} / \mathrm{lb} .=62.429 \mathrm{~cm}{ }^{\mathrm{z}} / \mathrm{g}$ ]

\begin{tabular}{|c|c|c|c|c|c|c|c|c|c|c|}
\hline${ }^{\circ} \mathrm{F}$ & $0^{\circ}$ & $1^{\circ}$ & $2^{\circ}$ & $3^{\circ}$ & $4^{\circ}$ & $5^{\circ}$ & $6^{\circ}$ & $7^{\circ}$ & $8^{\circ}$ & $9^{\circ}$ \\
\hline $\begin{array}{l}-100 . \\
=90 . \\
=80 . \\
=70 . \\
-60 .\end{array}$ & $\begin{array}{l}0.02197 \\
.02216 \\
.02236 \\
.02256 \\
.02278\end{array}$ & $\begin{array}{l}0.02195 \\
.02214 \\
.02234 \\
.02254 \\
.02275\end{array}$ & $\begin{array}{l}0.02193 \\
.02213 \\
.02232 \\
.02252 \\
.02273\end{array}$ & $\begin{array}{l}0.02191 \\
.02211 \\
.02230 \\
.02250 \\
.02271\end{array}$ & $\begin{array}{r}0.02190 \\
.02209 \\
.02228 \\
.02248 \\
.02269\end{array}$ & $\begin{array}{l}0.02188 \\
.02207 \\
.02226 \\
.02246 \\
.02267\end{array}$ & $\begin{array}{l}0.02186 \\
.02205 \\
.02224 \\
.02244 \\
.02265\end{array}$ & $\begin{array}{r}0.02184 \\
.02203 \\
.02222 \\
.02242 \\
.02263\end{array}$ & $\begin{array}{l}0.02182 \\
.02201 \\
.02220 \\
.02240 \\
.02261\end{array}$ & $\begin{array}{l}0.02180 \\
.02199 \\
.02218 \\
.02238 \\
.02259\end{array}$ \\
\hline $\begin{aligned}- & 50 . . \\
- & 40 . . \\
- & 30 . . \\
- & 20 . . \\
- & 10 . .\end{aligned}$ & $\begin{array}{l}.02299 \\
.02322 \\
.02345 \\
.02369 \\
.02393\end{array}$ & $\begin{array}{l}.02297 \\
.02319 \\
.02342 \\
.02366 \\
.02391\end{array}$ & $\begin{array}{l}.02295 \\
.02317 \\
.02340 \\
.02364 \\
.02388\end{array}$ & $\begin{array}{l}.02293 \\
.02315 \\
.02338 \\
.02361 \\
.02386\end{array}$ & & $\begin{array}{l}.02288 \\
.02310 \\
.02333 \\
.02357 \\
.02381\end{array}$ & $\begin{array}{l}.02286 \\
.02308 \\
.02331 \\
.02354 \\
.02378\end{array}$ & & $\begin{array}{l}.02282 \\
.02304 \\
.02326 \\
.02349 \\
.02374\end{array}$ & $\begin{array}{l}.02280 \\
.02301 \\
.02324 \\
.02347 \\
.02371\end{array}$ \\
\hline $\begin{array}{r}-\quad 0 . \\
+\quad 0 . \\
10 . \\
20 . \\
30 .\end{array}$ & $\begin{array}{l}.02419 \\
.02419 \\
.02446 \\
.02474 \\
.02503\end{array}$ & $\begin{array}{l}.02417 \\
.02422 \\
.02449 \\
.02476 \\
.02505\end{array}$ & $\begin{array}{l}.02414 \\
.02424 \\
.02451 \\
.02479 \\
.02508\end{array}$ & $\begin{array}{l}.02411 \\
.02427 \\
.02454 \\
.02482 \\
.02511\end{array}$ & & $\begin{array}{l}.02406 \\
.02432 \\
.02460 \\
.02488 \\
.02518\end{array}$ & $\begin{array}{l}.02404 \\
.02435 \\
.02462 \\
.02491 \\
.02521\end{array}$ & & $\begin{array}{l}.02399 \\
.02440 \\
.02468 \\
.02497 \\
.02527\end{array}$ & $\begin{array}{l}.02396 \\
.02443 \\
.02471 \\
.02500 \\
.02530\end{array}$ \\
\hline $\begin{array}{l}40 . . \\
50 . \\
60 . \\
70 . \\
80 .\end{array}$ & $\begin{array}{l}.02533 \\
.02564 \\
.02597 \\
.02632 \\
.02668\end{array}$ & $\begin{array}{l}.02536 \\
.02568 \\
.02601 \\
.02635 \\
.02672\end{array}$ & $\begin{array}{l}.02539 \\
.02571 \\
.02604 \\
.02639 \\
.02675\end{array}$ & $\begin{array}{l}.02542 \\
.02574 \\
.02608 \\
.02643 \\
.02679\end{array}$ & & & & & $\begin{array}{l}.02558 \\
.02590 \\
.02625 \\
.02661 \\
.02699\end{array}$ & $\begin{array}{l}.02561 \\
.02594 \\
.02628 \\
.02664 \\
.02703\end{array}$ \\
\hline $\begin{array}{r}90 . \\
100 . \\
110 . \\
120 . \\
130 .\end{array}$ & $\begin{array}{l}.02707 \\
.02747 \\
.02790 \\
.02836 \\
.02885\end{array}$ & $\begin{array}{l}.02711 \\
.02752 \\
.02795 \\
.02841 \\
.02890\end{array}$ & $\begin{array}{l}.02 \\
.02 \\
.02 \\
.02 \\
.02\end{array}$ & $\begin{array}{l}.02719 \\
.02760 \\
.02804 \\
.02851 \\
.02901\end{array}$ & & $\begin{array}{l}.02727 \\
.02769 \\
.02813 \\
.02860 \\
.02911\end{array}$ & & & $\begin{array}{l}.02739 \\
.02782 \\
.02827 \\
.02875 \\
.02927\end{array}$ & $\begin{array}{l}.02786 \\
.02832 \\
.02882 \\
.02930\end{array}$ \\
\hline $\begin{array}{l}140 \\
150 \\
160 \\
170 \\
180\end{array}$ & $\begin{array}{l}.02938 \\
.02995 \\
.03056 \\
.03124 \\
.03198\end{array}$ & $\begin{array}{l}.02943 \\
.03001 \\
.03063 \\
.03131 \\
.03206\end{array}$ & $\begin{array}{l}.02949 \\
.03007 \\
.03069 \\
.03138 \\
.03214\end{array}$ & $\begin{array}{l}.02954 \\
.03013 \\
.03076 \\
.03145 \\
.03222\end{array}$ & & $\begin{array}{l}.02966 \\
.03025 \\
.03089 \\
.03160 \\
.03238\end{array}$ & $\begin{array}{l}.02971 \\
.03031 \\
.03096 \\
.03167 \\
.03247\end{array}$ & & $\begin{array}{l}.02983 \\
.03045 \\
.03110 \\
.03183 \\
.03264\end{array}$ & $\begin{array}{l}.02989 \\
.03050 \\
.03117 \\
.03190 \\
.03272\end{array}$ \\
\hline $\begin{array}{l}190 \\
200 \\
210 \\
220 \\
230\end{array}$ & $\begin{array}{l}.03281 \\
.03375 \\
.03482 \\
.0361 \\
.0376\end{array}$ & $\begin{array}{l}.03290 \\
.03385 \\
.03494\end{array}$ & $\begin{array}{r}.03299 \\
.03395 \\
.03506\end{array}$ & $\begin{array}{r}.03309 \\
.03405 \\
.03518\end{array}$ & $\begin{array}{l}.0 \\
.0 \\
.0\end{array}$ & $\begin{array}{l}.03326 \\
.03426 \\
.03543 \\
.0368 \\
.0385\end{array}$ & $\begin{array}{r}.03336 \\
.03437 \\
.03556 \\
. \ldots \ldots \ldots\end{array}$ & $\begin{array}{l}.03346 \\
.03448 \\
.03569\end{array}$ & $\begin{array}{r}.03355 \\
.03459 \\
.03582\end{array}$ & $\begin{array}{r}.03365 \\
.03470 \\
.03595\end{array}$ \\
\hline $\begin{array}{l}240 \\
250 \\
260\end{array}$ & $\begin{array}{l}.0395 \\
.0422 \\
.0463 \\
.0577\end{array}$ & 0.0686 & & & & $\begin{array}{l}.0407 \\
.0440 \\
.0499\end{array}$ & & & & \\
\hline
\end{tabular}

- At $27 x .4^{\circ}$ (critical). 
Density of Liquid Ammonia under Saturation Pressure, In Pounds per Cubic Foot [1 lb. $\left./ \mathrm{ft}^{\mathrm{s}}=0.0160183 \mathrm{~g} / \mathrm{cm}^{\mathrm{s}}\right]$

\begin{tabular}{|c|c|c|c|c|c|c|c|c|c|c|}
\hline${ }^{\circ} \mathbf{F}$ & $0^{\circ}$ & $1^{\circ}$ & $2^{\circ}$ & $3^{\circ}$ & $4^{\circ}$ & $5^{\circ}$ & $6^{\circ}$ & $7^{\circ}$ & $8^{\circ}$ & $9^{\circ}$ \\
\hline $\begin{array}{r}-100 \ldots \ldots \\
-90 \ldots \ldots \\
-80 \ldots \ldots \\
-70 \ldots \ldots \\
-60 \ldots \ldots\end{array}$ & $\begin{array}{l}45.52 \\
45.12 \\
44.72 \\
44.32 \\
43.91\end{array}$ & $\begin{array}{l}45.55 \\
45.16 \\
44.76 \\
44.36 \\
43.95\end{array}$ & $\begin{array}{l}45.59 \\
45.20 \\
44.80 \\
44.40 \\
43.99\end{array}$ & $\begin{array}{l}45.63 \\
45.24 \\
44.84 \\
44.44 \\
44.03\end{array}$ & $\begin{array}{l}45.67 \\
45.28 \\
44.88 \\
44.48 \\
44.07\end{array}$ & $\begin{array}{l}45.71 \\
45.32 \\
44.92 \\
44.52 \\
44.11\end{array}$ & $\begin{array}{l}45.75 \\
45.36 \\
44.96 \\
44.56 \\
44.15\end{array}$ & $\begin{array}{l}45.79 \\
45.40 \\
45.00 \\
44.60 \\
44.19\end{array}$ & $\begin{array}{l}45.83 \\
45.44 \\
45.04 \\
44.64 \\
44.24\end{array}$ & $\begin{array}{l}45.87 \\
45.48 \\
45.08 \\
44.68 \\
44.28\end{array}$ \\
\hline $\begin{array}{l}-50 \ldots . . . \\
-40 \ldots \ldots \\
-30 . \ldots . . \\
-20 \ldots \ldots \\
-10 . \ldots . . .\end{array}$ & $\begin{array}{l}43.49 \\
43.08 \\
42.65 \\
42.22 \\
41.78\end{array}$ & $\begin{array}{l}43.54 \\
43.12 \\
42.69 \\
42.26 \\
41.83\end{array}$ & $\begin{array}{l}43.58 \\
43.16 \\
42.74 \\
42.31 \\
41.87\end{array}$ & $\begin{array}{l}43.62 \\
43.20 \\
42.78 \\
42.35 \\
41.91\end{array}$ & $\begin{array}{l}43.66 \\
43.24 \\
42.82 \\
42.39 \\
41.96\end{array}$ & $\begin{array}{l}43.70 \\
43.28 \\
42.86 \\
42.44 \\
42.00\end{array}$ & $\begin{array}{l}43.74 \\
43.33 \\
42.91 \\
42.48 \\
42.05\end{array}$ & $\begin{array}{l}43.78 \\
43.37 \\
42.95 \\
42.52 \\
42.09\end{array}$ & $\begin{array}{l}43.83 \\
43.41 \\
42.99 \\
42.57 \\
42.13\end{array}$ & $\begin{array}{l}43.87 \\
43.45 \\
43.03 \\
42.61 \\
42.18\end{array}$ \\
\hline $\begin{array}{r}-0 \ldots \\
+\quad 0 \ldots \\
10 \ldots \\
20 \ldots \\
30 \ldots\end{array}$ & $\begin{array}{l}41.34 \\
41.34 \\
40.89 \\
40.43 \\
39.96\end{array}$ & $\begin{array}{l}41.38 \\
41.29 \\
40.84 \\
40.38 \\
39.91\end{array}$ & $\begin{array}{l}41.43 \\
41.25 \\
40.79 \\
40.34 \\
39.87\end{array}$ & $\begin{array}{l}41.47 \\
41.20 \\
40.75 \\
40.29 \\
39.82\end{array}$ & $\begin{array}{l}41.52 \\
41.16 \\
40.70 \\
40.24 \\
39.77\end{array}$ & $\begin{array}{l}41.56 \\
41.11 \\
40.66 \\
40.20 \\
39.72\end{array}$ & $\begin{array}{l}41.61 \\
41.07 \\
40.61 \\
40.15 \\
39.68\end{array}$ & $\begin{array}{l}41.65 \\
41.02 \\
40.56 \\
40.10 \\
39.63\end{array}$ & $\begin{array}{l}41.70 \\
40.98 \\
40.52 \\
40.05 \\
39.58\end{array}$ & $\begin{array}{l}41.74 \\
40.93 \\
40.47 \\
40.01 \\
39.53\end{array}$ \\
\hline $\begin{array}{l}40 \ldots \\
50 \ldots \\
60 \ldots \\
70 \ldots \\
80 \ldots\end{array}$ & $\begin{array}{l}39.49 \\
39.00 \\
38.50 \\
38.00 \\
37.48\end{array}$ & $\begin{array}{l}39.44 \\
38.95 \\
38.45 \\
37.95 \\
37.43\end{array}$ & $\begin{array}{l}39.39 \\
38.90 \\
38.40 \\
37.90 \\
37.37\end{array}$ & $\begin{array}{l}39.34 \\
38.85 \\
38.35 \\
37.84 \\
37.33\end{array}$ & & & & $\begin{array}{l}39.15 \\
38.65 \\
38.15 \\
37.64 \\
37.11\end{array}$ & $\begin{array}{l}39.10 \\
38.60 \\
38.10 \\
37.59 \\
37.05\end{array}$ & $\begin{array}{l}39.05 \\
38.55 \\
38.05 \\
37.53 \\
37.00\end{array}$ \\
\hline $\begin{array}{r}90 \ldots \ldots \\
100 \ldots \ldots \\
110 \ldots \ldots \\
120 \ldots \ldots \\
130 \ldots . . .\end{array}$ & $\begin{array}{l}36.95 \\
36.40 \\
35.84 \\
35.26 \\
34.66\end{array}$ & $\begin{array}{l}36.90 \\
36.34 \\
35.78 \\
35.20 \\
34.60\end{array}$ & $\begin{array}{l}36.85 \\
36.29 \\
35.72 \\
35.14 \\
34.54\end{array}$ & $\begin{array}{l}36.80 \\
36.23 \\
35.67 \\
35.08 \\
34.48\end{array}$ & $\begin{array}{l}36.74 \\
36.18 \\
35.51 \\
35.02 \\
34.41\end{array}$ & $\begin{array}{l}36.67 \\
36.12 \\
35.55 \\
34.96 \\
34.35\end{array}$ & $\begin{array}{l}36.62 \\
36.07 \\
35.49 \\
34.90 \\
34.29\end{array}$ & $\begin{array}{l}36.56 \\
36.01 \\
35.43 \\
34.84 \\
34.23\end{array}$ & $\begin{array}{l}36.51 \\
35.95 \\
35.37 \\
34.78 \\
34.17\end{array}$ & $\begin{array}{l}36.45 \\
35.89 \\
35.32 \\
34.72 \\
34.10\end{array}$ \\
\hline $\begin{array}{l}140 \ldots \ldots \\
150 \ldots \ldots \\
160 \ldots \ldots \\
170 \ldots \ldots \\
180 \ldots \ldots\end{array}$ & $\begin{array}{l}34.04 \\
33.39 \\
32.72 \\
32.01 \\
31.27\end{array}$ & $\begin{array}{l}33.98 \\
33.33 \\
32.65 \\
31.94 \\
31.19\end{array}$ & $\begin{array}{l}33.91 \\
33.26 \\
32.58 \\
31.87 \\
31.11\end{array}$ & $\begin{array}{l}33.85 \\
33.20 \\
32.52 \\
31.80 \\
31.04\end{array}$ & $\begin{array}{l}33.78 \\
33.13 \\
32.45 \\
31.72 \\
30.96\end{array}$ & & $\begin{array}{l}33.65 \\
32.99 \\
32.30 \\
31.57 \\
30.30\end{array}$ & $\begin{array}{l}33.59 \\
32.93 \\
32.23 \\
31.50 \\
30.72\end{array}$ & $\begin{array}{l}33.52 \\
32.86 \\
32.16 \\
31.42 \\
30.64\end{array}$ & $\begin{array}{l}33.46 \\
32.79 \\
32.09 \\
31.35 \\
30.56\end{array}$ \\
\hline $\begin{array}{l}190 . . \\
200 \ldots \\
210 \ldots \\
220 \ldots \\
230 . .\end{array}$ & $\begin{array}{l}30.48 \\
29.63 \\
28.72 \\
27.7 \\
26.6\end{array}$ & $\begin{array}{c}30.40 \\
29.54 \\
28.62 \\
\ldots \ldots \ldots \\
\ldots \ldots \ldots\end{array}$ & $\begin{array}{r}30.32 \\
29.45 \\
28.53 \\
\ldots \ldots \ldots . \\
\ldots \ldots \ldots \ldots\end{array}$ & $\begin{array}{r}30.23 \\
29.37 \\
28.43 \\
\ldots \ldots . . . .\end{array}$ & $\begin{array}{r}30.15 \\
29.28 \\
28.33 \\
\ldots \ldots . . .\end{array}$ & $\begin{array}{l}30.06 \\
29.19 \\
28.23 \\
27.2 \\
26.0\end{array}$ & \begin{tabular}{|r|}
29.98 \\
29.10 \\
28.13 \\
$\ldots \ldots \ldots .$. \\
$\ldots \ldots . .$. \\
\end{tabular} & $\begin{array}{r}29.89 \\
29.01 \\
28.02 \\
\ldots \ldots \ldots \ldots \\
\ldots \ldots \ldots \ldots\end{array}$ & $\begin{array}{r}29.81 \\
28.91 \\
27.92 \\
\ldots \ldots \ldots . . . \\
\ldots \ldots \ldots . . .\end{array}$ & $\begin{array}{r}29.72 \\
28.82 \\
27.82 \\
\ldots \ldots . . .\end{array}$ \\
\hline $\begin{array}{l}240 . \\
250 . \\
260 . \\
270 .\end{array}$ & $\begin{array}{l}25.3 \\
23.7 \\
21.6 \\
17.3\end{array}$ & a14.6 & & & & $\begin{array}{l}24.6 \\
22.7 \\
20.1\end{array}$ & & & & \\
\hline
\end{tabular}

a At $27 \times .4^{\circ}$ (critical). 